\title{
Fraudulent Financial Reporting and the Consequences for Employees*
}

\author{
Jung Ho Choi
}

Brandon Gipper

\author{
Stanford University \\ Graduate School of Business
}

November 2019

\begin{abstract}
We examine employment effects, such as wages and employee turnover, before, during, and after periods of fraudulent financial reporting. To analyze these effects, we combine U.S. Census data with SEC enforcement actions against firms with serious misreporting ("fraud"). We find, compared to a matched sample, that fraud firms' employee wages decline by $9 \%$ and the separation rate is higher by $12 \%$ during and after fraud periods. Employment growth at fraud firms is positive during fraud periods and negative afterward. We explore the heterogeneous effects of fraudulent financial reporting, including thin and thick labor markets, bankruptcy and non-bankruptcy firms, worker movements, pre-fraud wage levels, and period of hire. Negative wage effects are particularly severe in thin labor markets, for bankrupt, fraud firms, and lower wage employees. However, some negative wage effects occur across these sample cuts, indicating that fraudulent financial reporting appears to create meaningful and prevalent consequences for employees. We discuss how our results can be consistent with channels such as labor market disruptions, punishment, and stigma.
\end{abstract}

\section{JEL classification: D83, J23, J31, M48, M51}

Key Words: $\quad$ Wages, Employment Growth, Accounting Fraud, Information Asymmetry, Stigma

* Contact: jungho@stanford.edu and gipperbr@stanford.edu. Any opinions and conclusions expressed herein are those of the authors and do not necessarily represent the views of the U.S. Census Bureau. All results have been reviewed to ensure that no confidential information is disclosed. We thank Ray Ball, Phil Berger, Nick Bloom, Hans Christensen, Steve Davis, Sheffield E Lesure, Christian Leuz, Frank Limehouse, Maureen McNichols, Darren Roulstone, Catherine Schrand (Discussant), and Sorabh Tomar and workshop participants at Ohio State University, Penn State FSRDC Conference, Santa Clara University, Stanford Summer Camp, and University of Southern California for helpful comments. We thank Sara Malik and Nick Maletta for research assistance and Patty Dechow, Henry Laurion, and Richard Sloan for access to AAER data. This research uses data from the Census Bureau's Longitudinal Employer Household Dynamics Program, which was partially supported by the following National Science Foundation Grants SES-9978093, SES-0339191 and ITR-0427889; National Institute on Aging Grant AG018854; and grants from the Alfred P. Sloan Foundation. We thank Stanford University for funding and the Centers and Initiatives for Research, Curriculum \& Learning Experiences for research assistance. 


\section{Introduction}

Accounting fraud is an important issue in the economy. Large accounting scandals occur regularly (e.g., Waste Management, Enron, WorldCom, Computer Sciences, Toshiba, and so on), and the consequences are usually significant. For example, Karpoff et al. (2008b) find that firms lose about $29 \%$ of equity value when the fraud is revealed. An extensive academic literature has also documented severe consequences of fraudulent reporting for other stakeholders, including customers, executives, and peer firms (e.g., Sadka, 2006; Desai et al., 2006; Beatty et al., 2013). However, prior papers rarely study labor market consequences, which can be large; for example, 17,000 workers lost jobs from WorldCom alone in June 2002 (Noguchi, 2002). In this paper, we examine these consequences of fraudulent financial reporting for employees. Specifically, we ask and answer several questions. Do employees suffer financially or benefit from accounting fraud in the form of higher wages prior to revelation? After revelation, do they suffer from wage declines or turnover? Do these effects vary in the cross-section, for instance by thickness of the labor market or period of hire? If we observe such effects, why?

Accounting fraud has three distinct features that make it important to examine these consequences. First, executives attempt to hide accounting fraud; this opacity could mislead employees as it does other stakeholders, like peer firms that make inefficient investment decisions using misleading financial information (e.g., Beatty et al., 2013). Second, papers in economics and finance have found consequences for employees from shocks to the firm, such as layoffs, regulation, offshoring, or bankruptcy. ${ }^{1}$ Employees are important stakeholders of the firm; their

1 For example, some papers include Jacobson et al. (1993), Walker (2013), Hummels et al. (2014), and Graham et al. (2016). Worker displacement often causes negative consequences in these settings; however, wages can go up when workers switch firms voluntarily (e.g., Mincer, 1986). 
long-run fortunes rise and fall with those of firms through, for example, investment in firm-specific human capital (Becker, 1993). Executives could take real actions during fraudulent reporting periods like overinvest in physical and human capital (Kedia and Philippon, 2009), and employees would suffer later when these excess investments are unwound, losing this specific capital or job hunting in unfavorable conditions. Third, executives mainly decide to misreport, but this corporate misconduct could have an effect on all of the employees. Workers can suffer from the reputation of their work history (Fama, 1980), so association with misconduct could cause penalty or stigma in future. These three features suggest that accounting fraud can be relevant for employees.

One important empirical challenge arises from our research questions; employee data are not commonly available. We use the Longitudinal Employer Household Dynamics (LEHD) and Longitudinal Business Database (LBD) datasets from the U.S. Census Bureau. These are an important data source for addressing questions related to employees in the United States (e.g., Hyatt and McEntarfer, 2012). These data contain workers' entire wage series across employers and a rich set of characteristics, such as worker age, education, gender, and employer location and industry. We combine this employer-employee data with Securities and Exchange Commission's Accounting and Auditing Enforcement Releases (AAERs) to proxy for fraudulent financial reporting. Our final sample includes about 200 cases of fraud at firms employing a worker in one of 23 states over the period 1991-2008; we use wage data from 414 thousand workers who were employed at these firms in the years leading up to the accounting fraud. ${ }^{2}$

2 Output from projects that use private U.S. Census data have strict rounding criteria that prevents us from providing a precise observation count in our analyses. In addition, the application process for using U.S. Census data for academic studies requires that individual states approve the project's use of data from that state. For an AAER case to enter our sample, the misreporting firm must have an employee in a participating state, among other sample criteria. 
For our main tests, we examine employee wages and turnover during and after fraudulent financial reporting between fraud and control samples. To select the control workers, we propensity score match the fraud firms to control firms within industry and year prior to the AAER misreporting. Control workers are employees of these control firms. This matching reduces endogeneity concerns about employee wage trends at firms that have firm characteristics associated with fraudulent reporting. Some challenges remain; fraud firms plausibly suffer a series of economic shocks (e.g., Schrand and Zechman, 2012) or have a unique employee composition. We use employer location and industry data within the LEHD to include specifications with extensive fixed effects to rule out shocks such as regional and industry downturns. We also vary our control sample. (i) We match firms using hand-collected firm data from the fraud period to control for temporal shocks. And (ii) we use the employee characteristics data from the LEHD to match subsamples of employees on these characteristics to control for unique worker compositions. ${ }^{3}$ These data and designs provide a reasonable approach to isolate the consequences of fraudulent financial reporting for employees.

We find that employees at fraud firms, compared to the matched control sample, have about 9\% lower earnings on average during and after periods of fraudulent financial reporting. This negative consequence is robust to a variety of specifications, including models with extensive fixed effects and various control groups. Descriptive splits show that worker displacement contributes substantially to these wage effects. These wage declines exist despite increased employment growth at fraud firms during the accounting fraud. During the fraud, firms shed existing workers, i.e., those employed in the pre-fraud period. These results combine to indicate that firms hire even

3 We also perform untabulated robustness tests and draw similar inferences, including the use of unmatched, random employees within industry and characteristic-matched employees within industry at otherwise unmatched firms. We caution that matching does not fully resolve endogeneity issues (e.g., Roberts and Whited, 2013). However, descriptive data still provide useful evidence on the consequences for employees at fraud firms. 
more employees that are new, causing a change to employee mix. Plausibly, executives engineer this composition change to show headcount growth and keep the wage bill low (e.g., as McNichols and Stubben, 2008, suggest with R\&D expenditures at fraud firms). New employees may join because fraudulent reporting prevents them from realizing that the "ship is sinking" (Brown and Matsa, 2016). We see negative employment growth at fraud firms after the fraud concludes. ${ }^{4}$ The separation rate at fraud firms is higher during and after the fraud period by $12 \%$ on average. Displaced workers are more likely to leave the industry and even the county, taking their next job (if any) elsewhere. The earnings drop and turnover is consistent with a story where workers are shocked by the fallout from the fraud and have lost firm-/industry-specific human capital, conduct job-search activities ineffectively, and/or enter crowded labor markets (e.g., Jacobson et al., 1993; Flaaen et al, 2018).

We examine the heterogeneous consequences for employees at three different levels to better understand these wage effects: at the market, firm, and individual level. First, we separately examine "thin" and "thick" labor markets, i.e., regions with few and many industry-specific employers, respectively. The wage declines are much stronger in thin labor markets, indicating that much of the effect likely comes from limited opportunities, consistent with workers job hunting in relatively crowded labor markets (e.g., Moretti, 2011). Second, we show the effects for employees at firms which ultimately go into bankruptcy and not. While the magnitude is larger for the bankruptcy subsample, we continue to find significant wage drops for the non-bankruptcy

4 This result is generally consistent with evidence from Kedia and Philippon (2009) who use employee levels from Compustat. They find greater employee growth during the fraud period and interpret it as overinvestment in labor. With the change in employee mix during the fraud, this interpretation is not complete. The departure of existing employees could be a "brain drain" that requires more new employees to perform the same work. Kedia and Philippon (2009) also find higher employee growth before the fraud period. For our control firms, we match on pre-fraud employee growth. When using the same matching variables as Kedia and Philippon (2009), we replicate their result, and our inferences for the effects on wages and turnover are unaffected. 
subsample, i.e., the effect is not isolated to employees of failed firms. Finally, we explore employee-level splits. These splits shed light on different mechanisms. Matched, leaving workers have negative wage effects, consistent with job search frictions for workers displaced by fraud (Christensen et al., 2005). Matched, early-leaving workers, i.e., those departing before the end of the fraud who are less likely to face job-search complications from fraud revelation, still experience declines in wages in the post-fraud period. Therefore, mechanisms other than labor market disruptions could have some effect on wages, such as workers suffer from the stigma associated with the fraud (e.g., Gibbons and Katz, 1991; Groysberg et al., 2017). Also, while executives are complicit and so are punished (e.g., Fama, 1980; Desai et al., 2006), we find that workers in the bottom $90 \%$ of the pre-fraud wage distribution (assumed not to be complicit executives) experience more negative wage effects during and after fraudulent financial reporting than the top $10 \%$ of employees., a novel result where consequences diverge from culpability.

We make several important contributions. First, our paper contributes to an extensive literature documenting other consequences of fraudulent financial reporting. Some papers show specific actions taken by firms because of the misreporting (e.g., Erickson et al., 2004; McNichols and Stubben, 2008; Kedia and Philippon, 2009). Other papers document broader cost estimates (e.g., Karpoff et al., 2008; Dyck et al., 2013). Our analyses improve upon the findings from these papers by measuring the dynamics of employee turnover and wages at the employee level. We show that although overall employment outflow starts after the fraud, some workers are displaced even during the fraud, and we show that wages decline during and after the fraud. These findings are consistent with highly disruptive and costly illegal misreporting, even trickling down to employees. An important subset of this literature documents fraudulent financial reporting consequences for executives and directors (e.g., Srinivasan, 2005; Desai et al., 2006; Karpoff et 
al., 2008a; Groysberg et al., 2017). We contribute to this literature by documenting that lowerlevel employees suffer consequences similar to those at the top after the fraud is revealed, for example, higher incidence of job exits. This benchmark is important because low-level employees are rarely party to the fraud, whereas executives (directors) perpetrate (fail at their monitoring duties to uncover) the misreporting, so one might expect consequences for the latter to be more severe.

Second, we contribute to another extensive literature documenting consequences for employees from a wide variety of shocks to firms (e.g., Gibbons and Katz, 1991; Jacobson et al., 1993; Couch and Placzek, 2010; Walker, 2013; Autor et al., 2014; Hummels et al., 2014; Graham et al., 2016) ${ }^{5}$. Across these many shocks, such as layoffs, outsourcing, bankruptcy, regulation, and so on, the consequences for employees are significant in terms of wages and worker flows. We show complementary evidence for fraudulent financial reporting. However, the channels for fraud are distinct. During the fraud, executives bring in new workers, increasing headcount, while existing employees leave and experience wage decreases, plausibly a shift to keep the wage bill low. After revelation, employees are displaced and have negative wage effects across subsamples, including workers that change jobs before the revelation. This widespread negative wage effect is

5 There are papers - in addition to Graham et al. (2016) - that examine headcount, wages, and unemployment (risk) for workers at distressed firms (e.g., John et al., 1992; Agrawal and Matsa, 2013; Falato and Liang, 2016). We discuss these papers more in Section 2. Similar to our data and research questions, Graham et al. (2016) use the U.S. Census LEHD data to examine effects for employees rather than firms, so we compare our findings to theirs. We believe that it is important to differentiate distress and accounting fraud, though the two are related. Accounting fraud is distinctive because this corporate event entails information asymmetry, overemployment, and reputational damage. They can be related; for example, Schrand and Zechman (2012) discuss a pattern in the AAER data where executives use fraud to cover up distress. However, for other AAERs, "misreporting firms are indeed more optimistically biased; it is not the case that they are equally optimistic about earnings in expectation but the misreporting firms simply get a bad draw on earnings" (Schrand and Zechman, 2012, p. 313, emphasis added). As discussed above and in Sections 4.3 and 5.2, we match to a control sample on unmanaged revenue growth during the fraud period and examine the subsample of fraud firms that avoid bankruptcy, respectively. Worker wage results are similar to our main results in these tests and are less likely to be driven by firm distress. 
plausibly a result of labor market disruptions and stigma from the fraud (e.g., Groysberg et al., 2017).

Third, our paper also has policy implications. We show labor market effects that can be useful inputs for evidence-based policymaking (Leuz, 2018). For example, regulatory reforms intended to reduce the burdens associated with mandatory financial reporting are often politically motivated by job creation. One case, the Jumpstart Our Business Startups Act (JOBS Act), reduced some disclosure and audit requirements for small and mid-sized IPO firms and was hailed by politicians for promoting job growth (Liberto, 2012), as evidenced by the tortured name that creates its acronym. In order to understand the total impact of such reforms, regulators need to consider both the capital market implications of such reforms, which are supposed to contribute to job growth, along with the labor market implications from a change in incentives to misreport. Our paper can contribute to that type of cost-benefit analysis while cautioning that there may be broader spillovers; we do not study undetected accounting fraud nor industry-wide effects. In addition, our finding that misreporting exacerbates labor market frictions could be considered alongside enterprise value to measure social costs of fraudulent financial reporting (e.g., Dyck et al., 2013).

\section{Literature Review and Mechanism Framework}

\subsection{Literature Review}

We summarize four streams of literature, two mentioned in the introduction, (i) consequences of fraudulent financial reporting, (ii) consequences for employees from shocks to the firm, (iii) an important subset of (ii): consequences for employees from firm distress, and (iv) associations between worker characteristics and financial reporting quality. 
One stream of literature has examined the broad consequences from accounting fraud for the firm and its peers. For instance, Erickson et al. (2004) show that firms incur real cash outflows to perpetuate fraud; namely, they overpay taxes. McNichols and Stubben (2008) show that firms overinvest in fixed assets, suggestive of internal information frictions. Kedia and Philippon (2009) show some effects related to ours with aggregated employee count and GAO restatement data. Kedia and Philippon (2009) also show overinvestment, consistent with McNichols and Stubben (2008), and have some evidence on increases in productivity after restatements. Beatty et al. (2013) investigate the spillover effects from high-profile accounting frauds on peers' investment, which increases during the fraud period and could be facilitated by equity analysts. Li (2016) builds on Beatty et al. (2013) to show that these peer spillovers are more general, not confined to high-profile fraud and observable in many types of investment, e.g., R\&D. Other papers document broader cost estimates; as mentioned in the introduction Karpoff et al. (2008b) find that firms lose about 29\% of equity value. Of the measured decline, only $12 \%$ is expected legal penalties while $88 \%$ is a reputational penalty. Dyck et al. (2013) finds that firms lose about $22 \%$ of enterprise value.

Academics also have documented the effects of fraudulent financial reporting for directors and executives, highly visible employees at the top of the firm. Early evidence from Agrawal et al. (1999) and Beneish (1999) suggested that firms suspected or charged with fraud did not have unusually high turnover among executives. Subsequent papers have documented significant career consequences for directors and executives. For restatements (not always fraud), Srinivasan (2005) finds in a three-year window that audit committee director turnover is $48 \%$ for firms that restate earnings downward and 33\% for a performance-matched sample. Desai et al. (2006) find that 60\% of restating firms turnover at least one top manager in a two-year window compared to $35 \%$ for matched firms. Karpoff et al. (2008a) examine SEC and Department of Justice enforcement actions 
and find that $93 \%$ of identified executives lose their job, with some facing criminal charges and penalties that include jail time. In a concurrent working paper, Groysberg et al. (2017) a firm's financial misconduct can affect pay for former executives not implicated in wrongdoing, which they attribute to "stigma," defined by the authors as a discrediting attribute or associated with other discredited entities. For example, the attribute could be higher likelihood of poor job performance. Depending on specification, Groysberg et al. (2017) find that average pay is 4-6\% lower for stigmatized executives in their panel. In contrast to these papers, our focus is on all employees and the heterogeneous effects of accounting fraud for different groups of employees.

Prominent papers in labor economics document costs to employees and cross-sectional variation of mass layoffs. For example, Gibbons and Katz (1991) present a theoretical model of layoffs: when firms can choose whom to lay off, the demand-side of the labor market infers that laid-off workers are of low ability, i.e., "lemons." They show evidence consistent with this among laid-off white-collar workers who experience about a 6\%-9\% wage decline, depending on specification. In their seminal paper, Jacobson et al. (1993) use administrative data from Pennsylvania to observe workers' wages in series; they find that high-tenure workers who separate from distressed firms suffer immediate (long-term) losses averaging 40\% (25\%) per year. Importantly for our analyses, they find that displaced workers' losses depend primarily on local labor-market conditions but not other worker attributes. More recently, Couch and Placzek (2010) revisit Jacobson et al.'s (1993) result due to concerns about magnitude estimates from a single, primarily industrial state during the 1970s and 80s. Couch and Placzek (2010) use administrative data from Connecticut and again find meaningful wage losses for displaced workers. They find that shortly after the separation, wages for workers displaced through mass layoff drop immediately (over the long-term, i.e., 6 years) $32 \%$ (12\%) percent. 
More recently, Walker (2013), Autor et al. (2014), and Hummels et al. (2014) examine the impact to employees from other shocks to firms, including environmental regulation, globalization, and offshoring, respectively. Walker (2013), estimating lost earnings from the Clean Air Act, finds affected workers lose, cumulatively, about $20 \%$ of their earnings on average. Autor et al. (2014) find that over 1992-2007, U.S. workers exposed to trade competition with China lose, again cumulatively, $46 \%$ of their earnings when moving across the inner quartile range. Finally, Hummels et al. (2014) examine the impact of offshoring on Danish workers' earnings; the authors find that, as an estimated size, when a firm doubles its offshoring, unskilled workers can expect cumulative wage losses of about $12 \%$. Skilled workers are not harmed and can even benefit while continuing to work for the firm. All three of these papers, and Couch and Placzek (2010), do find predictable cross-sectional effects, such as more harm to long-tenured workers, unlike Jacobson et al. (1993).

One important stream of literature examines the labor market impact of firm distress, which can raise wages as employees demand premiums for risk associated with distress and thus affect firms' decision-making. These papers often focus on financial distress or capital structure. An earlier paper that focuses on product market (rather than financial) distress and conditions the sample on recovery, John et al. (1992) show that firms very quickly shed about 5\%-6\% of their employees using levels data from Compustat. Using similar Compustat data, Whitaker (1999) shows that firms which take remedial actions, like cutting employees, during distress tend to recover. Their sample firms publicly announce that they are taking actions to recover from their poor performance, including reducing headcount. Agrawal and Matsa (2013) use changes to statelevel unemployment insurance laws to estimate that the indirect costs of financial distress associated with unemployment risk is equal to about 60 basis points of firm value (i.e., this is the 
cost to firms of attracting and retaining workers due to employment assurance benefits offered by firm stability; Baily, 1974). ${ }^{6}$ Consistent with these employment costs to workers, Falato and Liang (2016) find that debt covenant violations are associated with $10 \%$ drops in headcount. An important benchmark for our paper is Graham et al. (2016), who also use the U.S. Census LEHD data; they find that distressed firms pay wage premiums of about $12 \%$ and that in the event of bankruptcy, employees see wages drop by about $10 \%$ and are below pre-bankruptcy levels for six years, at least. Finally, Brown and Matsa (2016) show that job seekers understand and respond to firms' financial condition. As an employer's distress increases, it receives fewer and lower quality applicants for posted jobs. ${ }^{7}$ Building on these labor economics and finance papers, our paper documents that excessive optimism or unsuccessfully hiding bad performance backfires on the firms' employees due to misleading information, labor market disruptions, and stigmatization.

Finally, we discuss recent papers that document associations between employee characteristics and financial reporting quality, including fraud. Call et al. (2016) show that firms grant more options to non-top executive employees during periods of fraudulent financial reporting, consistent with firms providing incentives that deter whistle-blowing. Call et al. (2017) associate reporting quality with the average workforce education level in MSAs where the firm is headquartered and locations disclosed in 10-Ks; they find that firms with measured high-quality workers negatively correlate with absolute abnormal accruals, have fewer internal control violations, and fewer restatements. The authors conclude that workers can have an impact on the

6 In a working paper, using Swedish data, Baghai et al. (2018) show that firms do worse retaining talented employees when distressed. The firm-level conclusions are similar to Agrawal and Matsa (2013), except with employeremployee matched data: financial distress can be costly to the firm because employees value Baily (1974)-type insurance provided by the firm.

7 Other recent papers could also provide benchmarks for our results including, for example, the spillover effects from bankruptcy (Bernstein et al., 2018) or employee outcomes from other, major corporate transactions (e.g., Davis et al., 2014; Lee et al., 2018; Agrawal and Tambe, 2019). Bankruptcy spillovers, private equity investments, and merger and acquisition are associated with net job and wage losses, but the latter two are also associated with productivity gains. 
quality of financial reporting. There are also several working papers in this area. Hass et al. (2018) show that industry-level labor mobility is negatively related to regression-based estimates of real earnings management. These results suggest that worker mobility could "act as a disciplining mechanism discouraging firms from engaging in real earnings management." More closely related to our paper, the authors also show that restatement incidence is negatively related to mobility. ${ }^{8}$ Bai et al. (2018) use establishment-level US Census data to correlate disclosure quality and average wages for all employees. They document that firms with poorer disclosures pay their employees more both in the cross section and using SOX section 404 implementation as an instrument. In another concurrent working paper, Makridis and Zhou (2019) use Glassdoor employee ratings data to show that worker perceptions of firms decline during and after periods of misreporting. They also show some self-reported wage effects that appear to have a different time series pattern than ours. We contribute beyond these papers by using matched-firm and matched-individual samples, showing various labor market outcomes of current and former employees of accounting fraud firms and examining cross-sectional splits to provide evidence on mechanisms. Moreover, there is an emerging and rich literature associating financial reporting quality and social consequences to which our paper contributes. ${ }^{9}$

\subsection{A Framework for the Impact of Fraud on Labor Markets}

In this subsection, we propose a framework for the impact of fraud on labor markets, providing a structure to consider the connections between features of fraud and economic mechanisms that

8 While characteristics of the firm's workforce, such as mobility, might influence likelihood to commit accounting fraud, we show at the employee level what happens to employees during and after periods of serious, fraudulent financial reporting. Moreover, we want to document consequences of fraud for employees, rather than equilibrium predictors of it.

9 Another example, Holzman et al. (2019) document city crime spillover effects from fraudulent financial reporting. They show that financially motivated crime increases in cities where fraud firms are located, a consequence that could be related to our results of job turnover and lower wages. 
impact workers. We discuss three features of accounting fraud and associate these features with five mechanisms that could affect labor costs for workers, specifically wages and turnover. We depict these associations graphically as Figure 1.

\section{Information Asymmetry}

A preeminent feature of fraudulent financial reporting is that executives (or other perpetrators) are falsifying public information about the firm, which often shows better performance than the underlying economics. If workers keep or take a job in the presence of these informational asymmetries, they are misled about the likelihood of suffering a negative shock in the future. For example, if the firm does not improve under cover of the fraud and the fraud is revealed, employees only learn then that the firm has worse prospects compared to what had been falsely reported. Otherwise with accurate information about less optimistic or poor performance at the firm, employees might switch to or take a different job elsewhere (Brown and Matsa, 2016). For example, executives may use accounting fraud to defer the employee costs associated with financial distress (e.g., Agrawal and Matsa, 2013). Alternatively, fraud firms could be optimistically biased (i.e., not receiving a bad draw on earnings, as pointed out by Schrand and Zechman, 2012), and the employees could then be shocked by corrective actions (discussed more below) taken by the firm to reign in this bias. After a fraud is revealed, a theoretical explanation for displacement and lower wages is that employees cannot perform a thorough job search (Christensen et al., 2005). That is, they experience job-search frictions-on the job or after involuntary displacement — and so receive lower wages at their next jobs (e.g., Mincer, 1986; Addison and Portugal, 1989).

Overemployment: Hiring and Turnover Decisions 
Executives in accounting-fraud firms appear to overinvest in capital and may also over-hire employees in order to bolster the perception of the firm (McNichols and Stubben, 2008; Kedia and Philippon, 2009). This overinvestment would affect workers through two mechanisms. First, when employees work for a firm, they accumulate firm- (and industry-) specific human capital (Becker 1993). This specific capital loses value when the worker is displaced, which will happen when overinvestment is unwound. ${ }^{10}$ Second, due to overinvestment at the fraud firm or in the fraud firm's industry (e.g., Beatty et al., 2013), workers with similar skills are likely to lose jobs at the same time. Workers will be searching for their next job in an unfavorable local labor market condition: the labor market will be "crowded," i.e., many, similar workers will be looking for a job at the same time. Unwinding overinvestment would cause displacement. And both of these mechanisms, conditional on displacement, would be costly to workers in terms of wages. Similar effects have been shown in non-fraud settings (e.g., Jacobson et al., 1993; Couch and Placzek, 2010). These wage losses vary with tenure, mass layoffs, and local labor market conditions in ways consistent with firm-specific human capital and crowded labor markets.

\section{Misconduct}

A final feature of fraud is that a person or group of people commit an illegal act; if caught, the perpetrator(s) will be punished by both the legal system and the labor market (Fama, 1980). Prior literature has examined the incentives to commit fraud. Executives' private benefits and their narcissism or willingness to cover up problems can trigger accounting fraud (e.g., Beneish, 1999; Armstrong et al., 2010; Ham et al., 2017). Kedia and Philippon (2009) demonstrate that executives engage in both accounting fraud and insider trading for their private benefits. Schrand and

${ }^{10}$ Incomplete information about employer-employee matching quality generates earnings losses for switching workers as well; employees lose the informational value of firm-specific matching quality when displaced (Jovanovic, 1979). 
Zechman (2012) find that an executive's excessive optimism can result in accounting fraud. Also, as discussed above, prior literature has examined the labor market consequences of accounting fraud for those at the very top of the firm: e.g., observable executives like the CEO or directors (Srinivasan, 2005; Karpoff et al., 2008a). For example, Desai et al. (2006) find that executives experience turnover and poor job prospects. Moreover, to the extent that we have culpable individuals in our analysis, the punitive effects should match what prior literature has documented. The reputational damage from the misconduct of accounting fraud can also spill over to employees that were not involved. A fraud firm's bad reputation could negatively affect employees in the labor market through "stigma" (Groysberg et al., 2017). This stigma could also affect lower level employees that still rely on the reputation of former employers when seeking out a job or bargaining for wages.

\section{Data and Research Design}

\subsection{Accounting and Auditing Enforcement Releases}

Our sample for fraudulent financial reporting are the enforcement actions taken by the Securities and Exchange Commission (SEC). Specifically, we use Accounting and Auditing Enforcement Releases (AAERs). This sample identifies cases of accounting problems (among other enforcement actions taken by the SEC) that can be connected with prosecutable, fraudulent behavior by executives (Schrand and Zechman, 2012). We use UC Berkeley CFRM's dataset. Many prior papers have used these enforcement actions across a range of topics, for instance, to estimate, describe, and measure effects of fraudulent financial reporting (e.g., Feroz et al., 1991; Beneish, 1999; Farber, 2005; Dechow et al., 2011; Groysberg et al., 2017). 
Using the AAER sample involves a tradeoff where Type I errors for identified misreporting are very low but sample size tends to be small and spread out over many years (Dechow et al., 2010). ${ }^{11}$ The small sample size is less costly for this study because we use worker-years as the unit of analysis, increasing power. In addition, the long time series data mitigate a concern that our findings may be attributable only to specific time periods. Another tradeoff is that SEC enforcement priorities drive AAERs. Kedia and Rajgopal (2011) find that the SEC pursues cases at firms closer to the SEC and with higher media attention to be most effective with limited resources. In other words, the SEC could pursue more impactful cases because of resource constraints. These priorities may bias our results, measuring a larger impact, compared with the average accounting fraud. Finally, Karpoff et al. (2017) indicate CFRM data perform relatively well (i.e., see their Table 8) across a variety of metrics, except in measurement of the timing when stock market participants learn about the misreporting, though not in measuring the dates of misreporting periods. To overcome this challenge, we assume that misreporting is revealed to the public in a subsequent year to the misreporting period. This assumption is consistent with the finding of Karpoff et al. (2017) that stock market participants learn about the misreporting in about two months after the misreporting period on average.

\subsection{U.S. Census data}

We combine this AAER data with worker-firm matched data from the U.S. Census Bureau Longitudinal Employer-Household Dynamics (LEHD) and Longitudinal Business Database (LBD) data.

${ }^{11}$ Karpoff et al. (2017) echo some of these concerns with using AAER data. Our interest is in serious misreporting to measure the consequences for employees. We believe that AAERs match the data to the research question, consistent with Karpoff et al.'s (2017) recommendation to be careful with such matching. 
The LEHD data have a comprehensive coverage of workers, on average covering $96 \%$ of all private-sector jobs across years (e.g., Abowd et al., 2005). We have data from 23 states participating in the LEHD program. These data include wage data when the earnings are covered by a state's unemployment insurance program and generally include salaries, bonuses, equity, tips, and other perquisites (e.g., meals, housing, and retirement contributions, among others) (BLS, 2016). We observe these earnings as quarterly and annual pay. Self-employed, unemployed, and workers who move to non-participating states are not observable in the LEHD data. The data allow us to track the wages of workers who were employed at accounting-fraud firms but have since moved to other firms. We also use the individual characteristics provided by the LEHD data to separate the effects of misreporting and employee characteristics (e.g., gender, education, and experience) on wages. We require that employees are between 20 and 55 years old during the fraud period; this requirement generally limits the sample to workers who are (or desire to be) full-time participants in the workforce. We also require that the worker's annual real wages are higher than $\$ 2,000$ to exclude temporary workers.

The LBD data contain aggregated, establishment-level information (e.g., Davis et al., 2014; Giroud and Mueller, 2017). It covers the universe of non-farm industries from across the United States. The data come from the IRS and include variables such as wage bill and employment. We use these data to track employee growth within a misreporting firm over pre-fraud, fraud, and postfraud periods. ${ }^{12}$

\footnotetext{
12 The Compustat-SSEL Bridge (CSB) (covering 1981-2005) and the Standard Statistical Establishment List (SSEL) (covering later years) use primarily CUSIPs to link Compustat to LBD. We supplement these links by matching Employer Identification Numbers and company name, address, and industry in both data. We merge the Computstat-LBD data with the LEHD files using the Employer Characteristics Files (ECF). These linking files are widely used in prior literature (e.g., Graham et al., 2016; Giroud and Mueller, 2017). Finally, we merge with CFRM using CIKs (current and historical).
} 


\subsection{Research design and matching}

Our research design allows measurement of effects from fraud to be dynamic over the misreporting's lifecycle. We treat the misreporting as having three distinct periods. (i) "Pre-fraud" is the four-year period prior to the beginning of the fraudulent misreporting. (ii) "Fraud" is the period of time that mandatory financial information has been seriously misreported, later drawing SEC scrutiny, normalized to a maximum of three years. And (iii) "post-fraud" is the six-year period after the fraud is terminated, either through manager discontinuation, revelation, and/or firm failure. Although many accounting frauds are likely to be much more complex than a simple threeperiod event, we believe this categorization has several advantages. First, a common baseline in the pre-fraud period will help us select a plausible control sample to map out effects of the accounting fraud over later periods. Second, we are able to use the effects across multiple periods and subsamples to provide some evidence on various stories that may drive the results. Third, this research design is consistent with prior papers that examine firm actions during and after misreporting events (e.g., McNichols and Stubben, 2008; Kedia and Philippon, 2009). ${ }^{13}$ For most analyses, we examine existing employees, i.e., those employed in the pre-fraud period; though, we also use a sample of new employees, i.e., those hired during the fraud period, to show crosssectional effects.

We primarily use a matched sample of fraud and non-fraud firms to control for firm fundamentals because we are interested in the impact of accounting fraud, instead of firm

${ }^{13}$ McNichols and Stubben (2008) map out separate effects for the three years leading up to the misreporting, the first three years of misreporting (truncating later years), and the three years after misreporting. Kedia and Philippon (2009) measure average effects (i.e., combined) for the two years leading up to the restated period, all restated years, and the two years after the restated period. We use the disaggregated approach. In untabulated analyses, the "combined years" approach yields similar results. We normalize the fraud period to three years by counting subsequent years as additional "third years" to avoid separately identifying any fraud firms with descriptive data (i.e., long-lasting frauds) to comply with Census Bureau requirements. 
performance, on labor markets. When examining wages, we require that these firms be covered by the LEHD data (i.e., these firms will have at least one employee hired before fraud periods and one employee hired during fraud periods in one of the 23 states). We perform a propensity score match within industry-year, using 2-digit SIC industry codes from the firm-year prior to the AAER-identified misreporting. We match fraud firms' to non-fraud firms' characteristics in the year prior to the AAER-identified misreporting because fraud and non-fraud firms make different real decisions, such as investment, during a fraud period (e.g., McNichols and Stubben, 2008). We estimate the following cross-sectional probit model on the CFRM-Compustat-LBD-LEHD sample to obtain firm-year scores to match fraud to non-fraud firms:

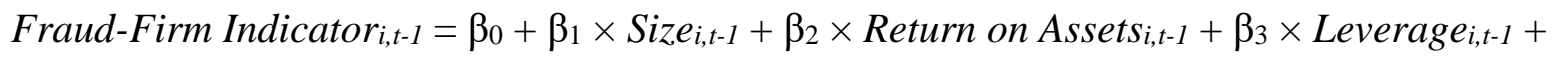

$$
\beta_{4} \times \text { Tobin's } Q_{i, t-1}+\beta_{5} \times \text { Employee Growth }{ }_{i, t-1}+\varepsilon_{i, t-1} .
$$

We give definitions in the Appendix Table A, and index firm with $i$ and fraud event-time with $t$. In Appendix Table B, we report the results of the probit model. Consistent with prior literature that matches on Size (e.g., Farber, 2005; Schrand and Zechman, 2012) and Tobin's $Q$ significantly and positively correlate with Fraud-Firm Indicator. Return on Assets and Employee Growth also positively correlate with Fraud-Firm Indicator. We include Leverage and Employee Growth in the model because prior papers indicate that these variables are correlated with employee wages and employee composition (Berk et al., 2010; Chemmaunur et al., 2013; Ouimet and Zarutskie, 2014)

Our main empirical tests use all observable employees from the fraud and non-fraud firm in our matched sample. We estimate wage effects, scaling wages using the CPI to 2010 price 
levels. ${ }^{14} \mathrm{We}$ estimate the following statistical specification characterizing workers' wages depending on work history (this is an unbalanced worker-year panel):

$$
\begin{aligned}
& \operatorname{Ln}\left(\text { Annual Real Wages } j_{j, \tau}\right)=\alpha+\beta_{1, \mathrm{p}} \times \sum_{\mathrm{p}=1,2,3,4} \operatorname{Pre}(t-p)_{j, \tau}+\beta_{2, \mathrm{p}} \times \sum \mathrm{p}=0,1,2 \operatorname{Fraud}(t+p)_{j, \tau}+ \\
& \beta_{3, \mathrm{p}} \times \sum_{\mathrm{p}=3,4,5,6,7,8} \operatorname{Post}(t+p)_{j, \tau}+\beta_{4, \mathrm{p}} \times \text { Fraud Ind. } \times \sum_{\mathrm{p}=1,2,3,4} \operatorname{Pre}(t-p)_{j, \tau}+
\end{aligned}
$$

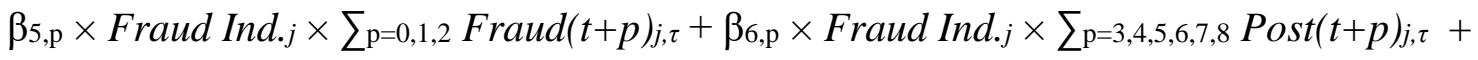

$$
\begin{aligned}
& \sum \beta_{\mathrm{m}}{\text { Worker Controls } \mathrm{s}_{j, \tau}+\sum \beta_{\mathrm{k}} \text { Fixed Effects } j, \tau}_{j}+\varepsilon_{j, \tau}
\end{aligned}
$$

We index worker with $j$ and calendar year with $\tau$. Fraud periods vary in calendar time depending on the worker. Worker controls include interactions of Female Indicator, Education, and Experience; the main effects are collinear with the fixed effects (e.g., Topel, 1991). ${ }^{15}$ In all specifications, we include worker and year fixed effects. We interact industry (and county) fixed effects with the year effects in some specifications. These controls generally follow Graham et al. (2016) and control for determinants of wages that could depend on the composition of the fraud and control firms' workforce and regional, industry-specific shocks. The period indicators nearly span the sample; we follow Graham et al. (2016) and have the baseline period be the two years prior to the $\operatorname{Pre}(t-4)$. We provide a detailed timeline in Figure 2 that map out these period indicators.

This specification is a difference-in-differences approach to estimate the effects of fraudulent financial reporting. $\beta_{4}$ is estimated wages for workers at fraud firms incremental to those at control firms prior to the misreporting. If the matches are reasonably well chosen, we expect the estimated

\footnotetext{
${ }^{14}$ When the data are missing, we do not infer zero wages. This measurement choice underestimates the costs of some job switches because we do not include the zeros for workers with long unemployment spells. An example where the worker is missing but does not have zero wages is a worker that has moved to another state not part of our data.

15 Experience is collinear with the main effects for the fraud periods (when measured as event-time year indicators), and we exclude this main effect from those specifications; that is, when Experience is demeaned by worker, it is effectively equivalent to a sequential count of the number of years in our sample.
} 
coefficient to be insignificantly different from zero and not exhibit any pre-fraud period trends. $\beta_{5}$ measures the incremental wages of fraud-firm employees for the fraud period. This measure is our first coefficient of interest; we infer the consequences for employees during the fraud from this coefficient estimate. $\beta_{6}$ measures the incremental wages for employees of fraud firms during the post-fraud period. This measure is our second coefficient of interest; we infer the consequences for employees after the fraud from the coefficient estimate. The identifying assumption for both of these coefficients is that wages would have evolved (in the absence of fraudulent financial reporting) for employees of AAER firms during and after the fraud as wages have evolved for control-firm employees.

Besides examining wages, we also map out employment growth in the pre, during, and post fraud periods from LBD data to measure firm-wide effects. This measure indicates dynamic job creation (destruction) across our three periods of fraud. We draw similar inferences from untabulated tests using Compustat and LEHD employment data. LBD data only counts U.S. employees; Compustat counts worldwide employees. LEHD data only counts employees in participating states.

\section{Main analyses}

\subsection{Sample description}

Table 1 Panel A provides comparisons of our matched fraud and non-fraud (control) firms. We find that our matching process described in section 3.3 generates a reasonably well-balanced sample. We perform the matching and measure these differences in the last year of the pre-fraud period. For the main tests, we match one-to-one on a firm basis but not an employee basis to focus on the effect of corporate events on employees, so matched firms with different numbers of 
employees would result in a larger treatment or control employee sample. In total, our sample contains about 200 fraud and 200 control firms. We do not find significant differences between fraud and control firms when comparing any of the control variables including Size, Assets, Return on Assets, Leverage, Tobin's $Q$, and Employee Growth. ${ }^{16}$ The average, firm-wide annual wages are comparable for fraud and matched control firms and equal to about $\$ 54$ or $\$ 55$ thousand normalized to 2010 CPI price levels. ${ }^{17}$

We show dynamics of employee growth over the life cycle of the pre-fraud, fraud, and postfraud periods. In Figure 3, we present the trend of fraud firms' employment decisions measured as year-on-year employee growth; we include growth at control firms for comparison. Compared with this control sample, we find positive employee growth among fraud firms in the fraud period; we see very high growth in both $\operatorname{Fraud}(t)$ and $\operatorname{Fraud}(t+1)$. Absolute (incremental) employee growth rises to $19 \%(9 \%)$ in the first year of the fraud then dips as the fraud continues in subsequent years. In the post-fraud period, we observe negative employee growth; the differences are meaningful for some years after the fraud ends, Post $(t+4), \operatorname{Post}(t+5), \operatorname{Post}(t+6)$, and Post $(t+7)$ have estimates of $-3 \%,-5 \%,-4 \%$, and $-3 \%$, respectively.

Table 1 Panel B gives descriptive statistics of firm characteristics for fraud firms with LEHD data, i.e., our sample, and all fraud firms with Compustat data. Firms with employees in more states have a higher likelihood of entering the LEHD data, so we expect our sample to contain

\footnotetext{
${ }^{16}$ Our matching model uses employee growth; consequently, there are statistically insignificant differences between fraud and matched-control firms in growth prior to the fraud period. This descriptive statistic differs from Kedia and Philippon (2009), who use employee levels from Compustat and do not match on employee growth. They find greater employee growth before the fraud period. When using the same matching variables as Kedia and Philippon (2009), we replicate their employment level results; our other main findings are not affected by this design choice.

17 Individual data that enter our sample have wages \$10 to \$20 thousand greater than these firm-wide average. One potential reason is that our main sample focuses on existing employees with two years of work experience at the firm, not all employees including both existing, new, and temporary employees as in the LBD data.
} 
larger and more mature firms. This is consistent with the relative magnitudes signed differences from Table 1 Panel B. Specifically, our sample fraud firms are larger, more profitable, have lower leverage, and have lower growth prospects. These differences are comparable to similar matching outcomes from prior literature (e.g., Table 1 Panel B in Graham et al., 2016). ${ }^{18}$

Table 2 presents descriptive statistics on the individual characteristics of employees of fraud and control firms. We construct our sample with existing employees to be included in tests, we require that she work for the sample firm in the two years prior to the fraud period, that is, $\operatorname{Pre}(t$ 2) and Pre(t-1). These data (and calculated differences) are from the last year of the pre-fraud period, Pre(t-1). At fraud firms, employees have similar education and gender. The annual real wage for individual workers in our sample is equal to about $\$ 73$ thousand at fraud firms (\$65 thousand at control firms). This is about $13 \%$ higher for our sample employees at fraud firms than matched control firm employees; although, this difference is not statistically significant. Employees at fraud firms are older by a year and a half and, consequently, have more experience. ${ }^{19}$

These two variables are highly related, so perhaps it is not surprising that these differences have similar magnitudes.

\subsection{Results for wages and displacement}

Table 3 contains our main result. We find consistently negative wage effects in the fraud and post-fraud periods for employees who work(ed) at fraud firms. We test for dynamic wage effects

\footnotetext{
${ }^{18}$ These differences indicate we may have some limitations to the generalizability of our results because fraud at larger firms could be wider reaching and, consequently, have a greater aggregate effect for employees. On the other hand, larger firms could be more durable and absorb shocks, mitigating effects for employees.

${ }^{19}$ In a robustness test, we match employees at fraud firms with employees at non-fraud firms using individual characteristics including, e.g., age and education. One concern of our main research design might be that employees working for fraud firms are different from employees working for non-fraud firms. By controlling for individual characteristics, we compare similar workers: one happens to work for fraud firms and the other happens to work for non-fraud firms.
} 
during and after fraudulent financial reporting to see the consequences for employees. Across columns, we increase the number of fixed effects. Specifically, in columns 1, 2, and 3, we estimate models with worker effects and year effects, year-industry, and year-industry-county effects, respectively. In column 1, we observe that employees in the pre-fraud period have negative wage changes compared with workers at non-fraud firms. The significance of this pre-fraud-period difference attenuates statistically in columns 2 and 3. We note that the magnitude of the wage drops from $\operatorname{Pre}(t-1)$ and $\operatorname{Fraud}(t)$ is consistent across columns, ranging between $6 \%$ and $8 \%$. Also, the average magnitudes for the post-fraud period are more negative than for the fraud period by $1 \%$ to $2 \%$. That is, the negative wage effect becomes more negative in event-time. Finally, the average wage effects in the fraud and post fraud periods are meaningfully negative, equal to about $-16 \%,-13 \%$, and $-9 \%$ in columns 1,2 , and 3 , respectively. To get a better sense of the trends, we depict column 3 graphically in Figure 4 with confidence interval estimates.

The magnitudes of the coefficients attenuate as additional effects are included, but the negative consequences are robust across different specifications. For example, the coefficients in column 3 are less negative than in column 2. This latter descriptive fact is consistent with both (i) frauds occurring and being revealed during (regional,) industry shocks and (ii) frauds being related to industry (and/or regional) spillovers (Beatty et al., 2013) and local labor market disruptions. The specification in column 2 controls for industry shocks, and the specification in column 3 controls for regional, industry shocks. In column 3, we remove the 24 thousand observations that are singletons from the sample. However, the wage drop is robust to these different specifications.

In Table 3, we also examine evidence for common trends using the first four coefficient estimates. We find that column 3 depicts small, insignificant coefficient estimates in the pre-fraud period without a consistent negative / positive sign, whereas coefficients for the fraud and post- 
fraud periods are negative and significant for all interacted indicators. In the first two columns, we observe some evidence that wage decreases pre-date the fraud period. The three later years (last year) of the pre-fraud period, $\operatorname{Pre}(t-3), \operatorname{Pre}(t-2)$, and $\operatorname{Pre}(t-1)$ (only $\operatorname{Pre}(t-1))$ ), has a negative coefficient that is significant at $\mathrm{p}=0.1$ threshold in column 1 (column 2). Otherwise, the estimated coefficients for the pre-fraud period are not significant (though negative). Overall, these tests indicate that the final set of controls removes much of the variation from local shocks that could pre-date the fraud. ${ }^{20}$ When controlling for these explanations, the onset of negative wage effects are relatively sharp and start around the fraud period for employees. We continue to use the specification with year-industry-county effects elsewhere in our analyses.

Next, we examine displacement. From the firm's perspective, there are three, straightforward reasons which explain why firms will use less labor in post-fraud periods. First, conditional on excess hiring during the fraud period, firms will reduce this inefficient hiring when the fraud concludes (Kedia and Philippon, 2009). Second, accounting fraud indicates some governance failure at the firm. Afterward, boards or shareholders could take away decision rights from executives and undertake projects with more caution, causing use of employee labor (and other inputs) to contract (Farber, 2005). Third, Schrand and Zechman (2012) show that excessive optimism (covering up small shocks) tends to precede fraud, which can unravel afterward if the shock worsens. Naturally, a firm's use of labor will decline with a negative shock, especially when the shock causes the firm to fail. Each of these effects would likely cause worker displacements as the firm contracts in the post-fraud period.

${ }^{20}$ Specifications that similarly include some combination of year, industry, and county effects do not have significant coefficient estimates among the pre-fraud indicators. For instance, (untabulated) a specification with year, industry, and county effects or year-industry and year-county effects have comparable results to column 3, though with consistently negative pre-fraud coefficient estimates that are not significant at conventional levels. 
In Table 4, we demonstrate that employees of fraud firms are more likely to leave a firm, an industry, and a county during or after fraud periods. We measure employee-level attrition in the first year of the fraud, $\operatorname{Fraud}(t)$, and the third and sixth years of the post-fraud period, $\operatorname{Post}(t+5)$ and Post $(t+8)$. We generate dummy variables that indicate whether an employee stays working (i) at the firm, (ii) in the industry, or (iii) in the county. For industry and county, we indicate with the industry and location of the employee's next job. ${ }^{21} \mathrm{We}$ present the averages for these dummies for employees of fraud firms in columns 1 and non-fraud firms in column 2. Employee attrition from the firm, industry, and county is high: these two-year tenured employees leave the non-fraud firms in the first year at rates of $9 \%, 9 \%$, and $12 \%$, respectively. The existing employees of fraud firms are more likely to leave in the fraud year by $3.5 \%$. Attrition from the fraud firm industry also appears to have a larger magnitude but this difference is not significant. Fraud firm employees do not incrementally leave the county for their next job. This displacement contrasts sharply with the results from Figure 3, where we saw higher employee growth at fraud firms. These two findings suggest that fraud firms are substituting new employees for long-tenured employees, changing the worker composition. If existing employees are more expensive than newly hired employees, executives plausibly engineer this composition change to show headcount growth and keep the wage bill low. ${ }^{22}$ The new employees may join because this fraud prevents them from realizing that

${ }^{21}$ If the worker has a subsequent, missing observation, we consider them to have left the firm, industry, and county. The "stay" county-level measure is biased downward if the worker stays unemployed in the same county. Alternatively, it could be that the worker leaves the county to a state that is not in our sample in order to stay at the same firm or in the same industry. So, we may underestimate "stays" for firm and industry.

${ }^{22}$ McNichols and Stubben (2008) find overinvestment in capital expenditures but find weaker overinvestment with $R \& D$ expenditures. They suggest that $R \& D$ reduces profits immediately, making it a less attractive type of investment to improve firm performance while perpetrating fraud. Employee wages are similar to R\&D: overinvestment in labor would be expensed presently. Shifting the worker composition toward cheaper, new employees could cause the firm to have the appearance of growth without the income statement expense. Alternatively, some employees may leave when it becomes apparent that the firm is experiencing a shock even though executives are attempting to hide this bad news with fraudulent financial reporting. 
the performance is worse than reported (Brown and Matsa, 2016) ${ }^{23}$ In both post fraud periods that we measure, existing employees of fraud firms are much more likely to be displaced, switching industries or moving her location to find new employment after the fraud, a costly, negative consequence related to fraudulent financial reporting. This result in the accounting fraud setting contrasts with the finding of Caggese et al. (2018) who examine a setting of financially constrained firms in Sweden. Different from increasing the proportion of new employees as fraud firms do in our sample, their sample firms fire new workers instead of existing workers. Caggese et al. (2018) interpret this as sub-optimal due to a distortion in the trade-off between current costs and future benefits to productivity of new workers.

We descriptively split the result by fraud employee movements to understand the source of these wage changes. We separate wage effects in the pre-fraud, fraud, and post-fraud periods for fraud-firm employees who (i) stay through at least three years in the post-fraud period ("stayer"), (ii) leave in the first year of the fraud period ("early leaver"), and (iii) leave after the first year of the fraud period but before three years in the post-fraud period ("late leaver"). We compare these subsamples with the average wage effects for workers at non-fraud firms. These results are descriptive because average wages for control workers include changes from regular job churn. So, we caution that workers conditioned on maintaining job status likely have other inherent differences (e.g., reliability) that can be consistent with higher wages or positive wage trends. However, these analyses help us understand where the negative wage effects occur, coinciding with displacements. In subsequent analyses (see Section 4.3), we also condition the control employees for staying or leaving the non-fraud firms.

${ }^{23}$ Another interpretation is that workers are able to identify that the firm is misreporting / has higher risks, so worker composition is changing to reflect the risk preferences of the employees (e.g., similar to the endogenous matching as shown with worker and firm age by Ouimet and Zarutskie (2014)). 
Figure 5 shows the results separated for fraud-firm-employee movements. We find that leavers experience most of the negative wage effects during both the fraud and post-fraud periods. The earnings drop and turnover is consistent with a story where workers are shocked by the fallout from the fraud and have lost firm-/industry-specific human capital, conduct job-search activities ineffectively, and/or enter crowded labor markets (e.g., Jacobson et al., 1993; Flaaen et al, 2018). Compared with the average control-firm worker, stayers have positive wage trends in the fraud and first three post-fraud years. When we stop conditioning on stayers' employment with the fraud firm, their pay returns to similar trends as all non-fraud, control employees. We show an interesting dynamic for fraud-firm employees who are early versus late leavers. Early leavers experience negative wage effects during the fraud period (i.e., when they leave the fraud firm) but afterward experience a recovery of wages. Late leavers, on the other hand, have negative wage effects in both the fraud and post-fraud periods, which is consistent with accounting fraud revelation causing disruption to local labor markets. These negative wage effects for late leavers are persistent through the end of the event-time series.

\subsection{Robustness}

As discussed above, our main sample uses one-to-one matches of firms in the year prior to fraud. We indicate our reasons for using the year prior, such as not ruling out effects from concurrent real decisions, etc. One concern with this design is that firms experience shocks that both (a) influence the executive's probability to fraudulently misreport performance and (b) affect the ability of the firm to maintain headcount and wages. Moreover, fraudulent financial reporting could be the executive's response to exogenous firm distress (Schrand and Zechman, 2012). If executives anticipate that firm distress would be compounded by employees demanding wage

premiums (e.g., Agrawal and Matsa, 2013; Graham et al., 2016), they may attempt to defer these 
costs by hiding the distress from employees with accounting fraud. So, the concern about negative shocks could be compounded by this response from the executives.

In a robustness test, we vary the control sample in response to this concern. We match firms using hand-collected firm data from the fraud period to control for temporal shocks. We separate the fraud sample into revenue misreporting and non-revenue misreporting. For the revenue misreporting subsample, we gather unmanaged sales data from, in order: (i) differences between Compustat-Snapshot “As First Reported - Annual” and "Most Recently Restated - Annual”, (ii) AAER reported annual misstatement amounts, (iii) restatements on SEC EDGAR database, and (iv) a Factiva and Google search for archival news documents reporting on the fraud. We use this hand-collected data to construct a Sales Growth variable measured from Pre(t-1) to Fraud(t) and include this variable in our propensity-score-matching model along with the other variables noted in equation (1). We estimate our main specification with this alternative control sample, including year-industry-county effects among other controls. We present the results in Table 5, column 1. The main findings are consistent using this alternative control sample. One coefficient, the estimate for incremental wages for fraud firm employees in period $\operatorname{Fraud}(t+1)$ is no longer significant at conventional levels. The magnitude decline in wages for this robustness test across fraud and post fraud period is about $-9.6 \%$, larger than the comparable specification for our main result.

Another concern with the main design is that fraud firms have a unique composition of workers that will have different wage trends during and after a fraud event. We use the employee characteristics data from the LEHD to match subsamples of employees from our matched fraud and control firms. We one-to-one match employees on age, education, experience, gender, and pre-fraud wage decile without replacement. Again, we estimate our main specification, including year-industry-county effects among other controls and present the results in Table 5, column 2 . In 
performing this subsample match, we lose 6.46 million employee-year observations ( $71 \%$ of our main sample), partially a consequence of the employee size differences between fraud and matched control firms shown in Table 2. The findings are weaker than our main result. While all negative, only coefficients for periods Fraud(t+2) and Post $(t+5)$ are significant at conventional levels. In addition, this subsample exhibits pre-trends where employees of fraud firms earn more in $\operatorname{Pre}(t-2)$ and Pre(t-1) compared to the control employees. The magnitude decline in wages for this test across the fraud and post fraud periods is about $-3.7 \%$. If we compare the wage drop in the fraud period to the averages at $\operatorname{Pre}(t-1)$, the magnitude is similar or larger than the wage declines from Table 3 (i.e., the main result: unmatched employees at matched firms). In other untabulated robustness tests, we match fraud firm employees to random employees within industry and characteristic-matched employees within industry at otherwise unmatched firms. The results of these alternative control groups are similar to our main results, with significant and negative wage effects in the fraud and post fraud periods.

\section{Heterogeneity across the Markets, Firms, and Workers}

\subsection{Market Heterogeneity: Thick and Thin Markets}

To understand better the source of these wage changes, we descriptively split the result by the character of the market where the employee works. Moretti (2011), in reviewing local labor markets, points out that thick labor markets provide insurance to workers (and firms) against idiosyncratic shocks. He writes, "The presence of a large number of other employers implies a lower probability of not finding another job." This intuitive logic resonates in fraud cases that are particularly harmful to small communities like how the WorldCom's fraud affected Clinton, MS 
(e.g., Noguchi, 2002). We expect the consequences of these frauds in thin labor markets to be particularly devastating for workers who do not have many other employer options.

We separately examine "thick" and "thin" labor markets, i.e., regions with many and few industry-specific employers, respectively. Table 6 shows this sample split in columns 1 and 2 . In column 1, we present estimates where the local labor market has many industry-specific employers, i.e., thick labor markets. Leading up to the fraud, fraud firms tend to give higher wages compared with the matched sample, $\operatorname{Pre}(t-2)$ and $\operatorname{Pre}(t-1)$ have coefficient estimates indicating $6 \%$ and $8 \%$ higher wages, respectively. ${ }^{24}$ This difference vanishes in the fraud period; wages start to trend downward. In the post fraud period, the fraud firms in thick labor markets pay less than the control firms but the estimates are not statistically significant, despite ranging between $6 \%$ and 9\%. The Post $(t+5)$ coefficient is significant at the $10 \%$ level. In column 2, we present estimates where the local labor market has few industry specific employers, i.e., thin labor markets. Employees in these labor markets do very poorly. There are lower wage trends leading into the fraud period. The negative wage effects in the fraud and post fraud periods are large, e.g., point estimates more negative than $-13 \%$ for almost all coefficients. We map out these effects in Figure 6 Panel A. Overall, the wage declines are much stronger in thin labor markets, indicating that much of the effect likely comes from displacement into crowded labor markets and frictions to effective job-searches (e.g., Moretti, 2011).

${ }^{24}$ Fraud firms in thick labor markets appear to have positive pre-fraud period trends which then reverse. This sample split could be correlated with the type of fraud firm. For example, these firms plausibly are in more competitive product markets and so are differentially paying employees due to the economics of these product markets, like increasing compensation for employees to aggressively increase sales. 


\subsection{Firm Heterogeneity: Bankruptcy and Non-Bankruptcy}

Another source of variation that is relevant for understanding the consequences for employees is the seriousness of the fraud or seriousness of the shock that the fraud is hiding. The seriousness of the fraud is related to the magnitude of the consequences in other settings; for example, Srinivasan (2005) finds that as the magnitude or duration of restatements increases, outside directors on the audit committee are more likely to turnover. Related, many big frauds can be associated with firm failure, e.g., Enron in late 2001 and early 2002 (SEC, 2004). In addition, Graham et al. (2016) examine the wage effects of bankruptcy (independent of fraudulent reporting) and find negative consequences for employees in the post-bankruptcy period. We want to both (i) see if the consequences vary with seriousness of the fraudulent misreporting and (ii) determine whether serious firm distress or firm failure can fully explain our results.

To provide evidence on this variation, we examine bankruptcy and non-bankruptcy fraud firms. Bankruptcy firms likely receive a series of shocks or very severe shocks. Non-bankruptcy firms could be the other explanations: unwinding excesses from executive optimism or governance-driven contractions. For this subsample analysis, we retain the matched-control firm for bankrupt and non-bankrupt fraud firms; that is, the control firms are not divided on subsequent, bankrupt status. Table 6 shows this sample split in columns 3 and 4 . The trends in both columns in the pre-fraud period are not significantly different from zero. In column 3, we present estimates where the fraud firm declares bankruptcy within three years after the fraud period. Employees of bankrupt fraud firms have only small declines in wages in $\operatorname{Fraud}(t)$. Subsequently, there is a sharp drop in wages. The magnitudes in the post fraud period range between $-27 \%$ and $-17 \%$, recovering in the later years. Wage drops for employees of bankrupt fraud firms is severe. We can compare these magnitudes to Graham et al. (2016) who examine the wage effects of bankruptcy 
(independent of fraudulent reporting). They find that wages deteriorate by $10 \%$ when a firm files for bankruptcy. As a rough comparison, the wage consequences for employees is greater when the executives commit fraud and file for bankruptcy rather than file for bankruptcy alone. In column 4, we present estimates where the fraud firm does not declare bankruptcy within three years after the fraud period. The negative wage effects in the fraud and post fraud periods occur right away and are highly persistent, though are much less severe than the bankruptcy subsample, fluctuating between $-6 \%$ and $-12 \%$. We also map out these effects in Figure 6 Panel B. Note that the observation count for this non-bankruptcy subsample is the majority of our full sample. While devastating, bankruptcies do not drive the overall wage decline during and after fraudulent financial reporting in our main analysis, even employees at fraud firms with much less severe shocks suffer negative consequences.

\subsection{Employee Heterogeneity: Movements, Pre-Fraud Wages, and New Hires}

A final source of variation that can help inform why employees suffer these negative wages around fraud comes from the employees themselves. From the employee's perspective, accounting fraud may lead to inefficient labor choices. The worker is making an important decision when accepting a new job; he or she could be losing firm-specific rents at an old job (Jacobson et al., 1993), choosing to make new specific investments at the next job (Becker, 1993), and so on. The employee plausibly chooses to work for firms involved in accounting fraud, because (media coverage about) false financial performance suggests good prospects at the firm. This financial misrepresentation makes specific investments with the fraud firm appear to be relatively attractive (Lazear, 2009). So, workers stay at or join the fraud firm in the presence of information asymmetries; then the fraud is revealed, and workers are displaced or leave suddenly. A theoretical explanation is that employees cannot perform a thorough job search. Moreover, they have 
conducted job-search activities ineffectively, on the job or after a separation, so receive lower wages at their next jobs (e.g., Mincer, 1986; Addison and Portugal, 1989; Christensen et al., 2005). Similar to these job search frictions, local labor market conditions could play a role. Many former, similar employees could be job hunting at the same time, so this "crowded" labor market would also negatively affect the job prospects for former employees (e.g., Jacobson et al., 1993; Moretti, 2011; Bernstein et al., 2018).

We provide evidence for these mechanisms by using worker movements both at fraud and matched control firms. We examine the subsample of employees who leave before three years in the post-fraud period ("leaver"); this subsample includes leavers from both fraud and matched control firms. So, we condition on a job change for employees at both fraud and non-fraud firms. We show these results in column 1 of Table 7 . Leavers of fraud firms experience a sharp drop in wages during the fraud period that are persistent and negative throughout the fraud and post fraud periods, starting at $-5 \%$ in $\mathrm{Fraud}(t)$ and trending down to about $-11 \%$ to $-13 \%$. Job search frictions and local labor market conditions for former employees of fraud firms could drive this result; these workers may have less time to prepare for a job change and enter labor markets that are crowded (and negatively shocked) with other workers that have a similar skill set. For example, former energy traders from Enron likely had little time to prepare for a job transition in early 2002 and entered a crowded field of other workers with similar skills in the Houston area.

Fraudulent financial reporting can also affect employees as they interact with their next employer. A fraud firm's reputational damage could negatively affect employees in the labor market through "stigma." That is, even though an employee is not obviously involved with the financial-reporting fraud, other employers could associate that portion of the worker's job history 
with the reputation of the firm, which is damaged from the revealed fraud. ${ }^{25} \mathrm{We}$ examine an additional subsample of leaver employees, those who leave in the first year of the fraud period, $\operatorname{Fraud}(t)$ ("early leaver"). That is, these workers leave before the fraud is revealed. Again, we condition on a job change for employees at both fraud and non-fraud firms. These results are in column 2 of Table 7. Despite this pre-fraud revelation job switch, former fraud-firm workers experience negative wage effects in the post-fraud period. This evidence could be consistent with a "stigma" effect for these workers. Although they no longer work for the fraud firm and are not necessarily changing jobs in the post-fraud period, they still experience negative consequences after the fraud. ${ }^{26}$ We map out these results, matched stayers, leavers and early leavers, in Figure 7 Panel A.

For completeness, we separately examine a subsample of employees who stay through at least three years in the post-fraud period (“stayer"). In Table 7, we present results for stayers in column 3. We find that these employees have both positive and negative wage effects in the fraud periodstarting at $-2.5 \%$, jumping to $3 \%$ (both not significant), and dropping to $-6 \%$ - and later in the post fraud period - again starting at $-2.5 \%$ (again, not significant) and dropping to between $-6.5 \%$ and $-11 \% \cdot .^{27}$

25 This reaction of hiring managers may be behavioral; the worker could have the same skills and productivity as other applicants but is hired less often or paid less (Groysberg et al., 2017). Alternatively, the other employers are responding to some probability that a worker from the now-revealed fraudulent firm is less productive or may have been involved in the fraud (Gibbons and Katz, 1991).

${ }^{26}$ Another possible explanation is that the new job obtained during the fraud period was a worse match compared to new jobs for control workers due to the limitation of job search (Agrawal and Tambe, 2019). For example, we see significant negative wage effects during Fraud( $t+2)$, i.e., for long-lasting frauds, after the worker switches.

27 This pattern could be consistent with lower investment in human capital or lower returns to investment in human capital. For example, when capital markets penalize fraud firms in the post fraud period (e.g., Karpoff et al., 2008b), these firms may have fewer resources for training employees, hence the slowly downward trending effects, rather than the sharp drop. 
Among employees, some must have perpetrated the fraud. Much of the prior literature has examined executives' private benefits and their optimism (or narcissism) both as triggers of accounting fraud (e.g., Beneish, 1999; Armstrong et al., 2010; Schrand and Zechman, 2012; Ham et al., 2017). Also, prior literature has examined and found serious consequences for executives (e.g., Desai et al., 2006; Karpoff et al., 2008a). If highly paid workers are executives who are culpable — at least in part—for the misreporting, we expect to have negative wage consequences concentrated among the highly paid as labor markets "settle up" (Fama, 1980). Moreover, our results could be the consequences of punitive effects already documented by prior literature.

We use pre-fraud variation in pay to provide some evidence on whether we only measure an effect for culpable executives being punished in the labor market or if non-executives also suffer wage drops around fraudulent financial reporting. For columns 4 and 5 in Table 7, we present analyses that condition on the pre-fraud period wage level across firms. We split the sample into workers who are in the top $10 \%$ of the wage distribution ("top 10\%") and the bottom $90 \%$ of the distribution ("bottom 90\%"). Bottom 90\% workers are unlikely to have perpetrated the misreporting. So we expect that any wage consequences for these workers are the result of disruption in labor markets and / or stigma. In column 4, employees in the top $10 \%$ do not suffer significant negative consequences during or after the fraud period. ${ }^{28}$ A portion of this "nonnegative" result could be a run up in wages in $\operatorname{Pre}(t-2)$ and $\operatorname{Pre}(t-1)$. Overall, the negative dip in pay during and immediately after the fraud is not severe and not statistically significant using this

${ }^{28}$ We show results from a specification with year-industry-county effects estimated within the top $10 \%$ using 893 thousand observations. If there are very few top $10 \%$ employees in an industry-county during some year, we might be "over controlling" for some of the effect that we want to measure. Using a specification with only year-industry effects with the top $10 \%$ subsample, we find consistent, negative coefficients throughout the fraud and post-fraud periods. The average wage magnitude relative to top $10 \%$ employees at control firms for these periods is $-16.4 \%$. Also, if top $10 \%$ employees are more mobile, we could underestimate the negative impact by missing observations for those that take their next job in states that do not provide data for our study. 
specification for the top 10\% subsample. Bottom 90\% employees, however, experience significant, negative wage effects in the fraud and post-fraud periods, around $-7 \%$ to $-9.5 \%$ and $-8 \%$ to $-13 \%$, respectively. Workers in the bottom $90 \%$ of the wage distribution have worse wage consequences from fraudulent financial reporting despite the lower likelihood that they are involved with the fraud. This result supports and, at the same time, contradicts the findings of John et al. (1992). In their paper, financially distressed firms cut their employees rapidly. However, those firms, at the same time, exhibit no significant turnover in top managers. On the other hands, accounting fraud brings about negative consequences for the entire labor force. We map out these results also in Figure 7 Panel B.

Our final employee characteristic is the period of hire. We have already shown that existing employees leave the firm during and after the fraud but during the fraud, these misreporting firms have high employee growth. We think that it is natural to examine these new employees that join during the fraud period to shed some light on, perhaps, why they join and what earnings consequences do they experience. We use a separate sample of "new employees" in Table 7, we require that she not work for the sample firm in the year prior to the fraud period, Pre(t-1), and work for the firm for the first year of the fraud period, $\operatorname{Fraud}(t)$. New employees at the matched control firms are also joining in the same, event-time year.

We present the results for new employees in Table 8, which has a similar structure to the main result for existing employees in Table 3. We increase the fineness of fixed effects, estimating models with worker effects and year effects, year-industry, and year-industry-county effects in columns 1,2, and 3, respectively. Across all columns, new employees have negative wage effects in the post fraud period (only significant for Pre(t+5) onward in column 3) in the range of $-5 \%$ through $-18.5 \%$, depending on specification. Additionally, new employees at fraud firms generally 
have lower wages in the pre-fraud period, particularly two years before hire: Pre(t-2). Finally, in column 3 there is some weak evidence that new employees may initially benefit from this employee growth that fraud firms have in $\operatorname{Fraud}(t)$; new employees have slightly positive wages, relative to new employees at control firms, equal to about $8 \% .{ }^{29} \mathrm{We}$ present the results from column 3 in Figure 8.

Overall, these new employees may benefit when being hired into the firm but have long-term, negative wage consequences. The cumulative impact for new employees at fraud firms, relative to those at control firms, including the hire-year wage bump, is equal to about $-15 \%$ to $-2 \%$, depending on specification. These new employees (and the "stayers" among the existing employees discussed above) suffer from firm-specific information asymmetry when executives perpetrate fraudulent financial reporting, experiencing wage declines in the long run. ${ }^{30} \mathrm{New}$ employees may join because fraudulent reporting prevents them from knowing that the firm performance is deteriorating. Otherwise, they might have otherwise taken a different job elsewhere (Brown and Matsa, 2016). ${ }^{31}$

\section{Conclusion}

This paper provides evidence on the consequences for employees from fraudulent financial reporting. We use employer-employee matched data from the U.S. Census Bureau combined with

${ }^{29}$ Alternatively, if workers are aware of (or suspect) accounting fraud, then they would likely require wage premiums for risk-sharing with such firms, anticipating some chance that the fraud is revealed and the firm suffers. Instead, a near absence of wage increases for new employees combined with employment growth at fraud firms suggests that workers would not identify the accounting fraud and thus would not price protect against it.

${ }^{30}$ It is unclear whether the fraud allows the employee to fully understand the risks associated with joining this firm. If new workers accept this job in the presence of these informational asymmetries about firm performance, they accept despite the increased likelihood of suffering a negative wage shock in the future when the fraud is revealed, i.e., the workers do not anticipate future wage declines that the firm cannot protect against (Baily, 1974; Guiso et al., 2005; Graham et al., 2016).

31 Alternatively, fraud firms are increasing headcount and may need to make favorable wage offers to attract new employees as there exists some uncertainty about the firm's reputation given the poor information environment or distress associated with accounting fraud (e.g., Benson et al., 2019). 
SEC enforcement actions against firms with serious misreporting ("fraud") to examine wages and employee turnover. Compared to the employees at non-fraud control firms, we find that employees at fraud firms have lower wages during and after periods of fraudulent financial reporting even though fraud firms have higher employment growth during the fraud. During the fraud, executives appear to change employee composition. Also, we find that employees at fraud firms are more likely, compared to a matched sample, to leave the firm, industry, and (even) county of employment after the fraud is revealed while fraud firms have negative employee growth.

We discuss and show evidence consistent with mechanisms for these wage effects. The negative change in wages combined with employee displacement and negative employment growth at fraud firms indicates workers suffer negative labor market outcomes, for instance losses of firm-specific investments, job search inefficiency, and/or entering crowded labor markets. Wage losses are worse in thin labor markets and for fraud firms that ultimately declare bankruptcy. However, employees of non-bankrupt fraud firms also suffer wage declines, so the effects are not isolated to failed firms. We examine early-leaving workers (less affected by job search inefficiencies, e.g., Jacobson et al., 1993) and workers in the bottom $90 \%$ of the pre-fraud wage distribution (less affected by punishment for culpability, e.g., Fama, 1980) and continue to find negative wage effects during and after fraudulent financial reporting. This could indicate that stigma plays some role even for lower-level employees (e.g., Groysberg et al., 2017).

We note several important caveats. First, we show evidence that could be consistent with certain mechanisms; however, we are unable to isolate the specific effects from any single channel. For instance, the stigma from the fraud and disruption to labor markets are both related to the severity of the fraud and likely economic shocks to the firm. Consequences for employees can be caused by many explanations even when we perform sample splits. Second and related, matched 
difference-in-differences designs do not necessarily show causation (Roberts and Whited, 2013). We find effects that happen concurrently, with little evidence for pre-period trends, so we are confident these effects are associated with the fraud but not necessarily caused by it. Third, SEC enforcement priorities could respond to more severe employee consequences rather than neutrally target cases of serious misreporting. When employees are investors of the firm and suffer concentrated, negative consequences to their retirement portfolios (e.g., Ball, 2009), the SEC plausibly views this firm and its executives as an important target for enforcement. So, the magnitudes that we estimate could, in part, be driven by our use of AAER data. Overall, these concerns suggest interpreting our findings with caution; however, our results are useful for addressing the research questions. For instance, we find consistent results across the descriptive sample splits, using matching and well-controlled regression specifications, and these findings are shown with the unique combination of SEC enforcement actions and US Census data. 


\section{References}

Abowd, John M., Bryce E. Stephens, Lars Vilhuber, Fredrik Andersson, Kevin L. McKinney, Marc Roemer, and Simon Woodcock. "The LEHD Infrastructure Files and the Creation of Quarterly Workforce Indicators.” U.S. Census Bureau, Suitland, MD (2005).

Addison, John T., and Portugal, Pedro. "Job Displacement, Relative Wage Changes, and Duration of Unemployment.” Journal of Labor Economics 7.3 (1989): 281-302.

Agrawal, Anup, Jeffrey F. Jaffe, and Jonathan M. Karpoff. "Management turnover and governance changes following the revelation of fraud." The Journal of Law and Economics 42-S1 (1999): 309-342.

Agrawal, Ashwini K., and David A. Matsa. "Labor unemployment risk and corporate financing decisions." Journal of Financial Economics 108.2 (2013): 449-470.

Agrawal, Ashwini K., and Prasanna Tambe. "Takeovers and Endogenous Labor Reallocation" Working paper (2019).

Armstrong, Christopher S., Alan D. Jagolinzer, and David F. Larcker. "Chief Executive Officer Equity Incentives and Accounting Irregularities." Journal of Accounting Research 48.2 (2010): 225-271.

Autor, David H., David Dorn, Gordon H. Hanson, and Jae Song. "Trade adjustment: Worker-level evidence.” The Quarterly Journal of Economics 129.4 (2014): 1799-1860.

Baghai, Ramin P., Rui C. Silva, Viktor Thell, and Vikrant Vig. "Talent in Distressed Firms: Investigating the Labor Costs of Financial Distress." Working paper (2018).

Bai, John (Jianqui), Matthew Serfling, and Sarah Shaikh. "Accounting Disclosures and Employee Wages." Working paper (2018).

Baily, Martin Neil. "Wages and employment under uncertain demand." The Review of Economic Studies 41.1 (1974): 37-50.

Ball, Ray. "Market and Political/Regulatory Perspectives on the Recent Accounting Scandals." Journal of Accounting Research 47.2 (2009): 277-323.

Beatty, Anne, Scott Liao, and Jeff Jiewei Yu. “The spillover effect of fraudulent financial reporting on peer firms' investments." Journal of Accounting and Economics 55.2-3 (2013): 183-205.

Becker, Gary S. "Human capital revisited." Human Capital: A Theoretical and Empirical Analysis with Special Reference to Education ( $3^{\text {rd }}$ Edition). The University of Chicago press, 1993 $15-28$.

Beneish, Messod D. "Incentives and penalties related to earnings overstatements that violate GAAP." The Accounting Review 74.4 (1999): 425-457.

Berk, Jonathan B., Richard Stanton, and Josef Zechner. "Human capital, bankruptcy, and capital structure", Journal of Finance 65.3 (2010): 891-926.

Benson, Alan, Aaron Sojourner, and Akhmed Umyarov. "Can reputation discipline the gig economy? Experimental evidence from an online labor market." Management Science Forthcoming (2019). 
Bernstein, Shai, Emanuele Colonnelli, Xavier Giroud, and Benjamin Iverson. "Bankruptcy Spillovers." Journal of Financial Economics Forthcoming (2018).

Brown, Jennifer and David A. Matsa. "Boarding a Sinking Ship? An Investigation of Job Applications to Distressed Firms." The Journal of Finance 71.2 (2016): 507-550.

US Bureau of Labor Statistics (BLS). "Quarterly Census of Employment and Wages: Handbook of Methods." https://www.bls.gov/cew (2016).

Caggese, Andrea, Vincente Cunat, and Daniel Metzger. "Firing the Wrong Workers: Financing Constraints and Labor Misallocation." Journal of Financial Economics Forthcoming (2018)

Call, Andrew C., Simi Kedia, and Shivaram Rajgopal. "Rank and file employees and the discovery of misreporting: The role of stock options." Journal of Accounting and Economics 62.2-3 (2016): 277-300.

Call, Andrew C., John L. Campbell, Dan S. Dhaliwal, and James R. Moon Jr. "Employee quality and financial reporting outcomes." Journal of Accounting and Economics 64.1 (2017): 123149.

Chemmanur, Thomas J., Yingmei Cheng, and Tianming Zhang. "Human capital, capital structure, and employee pay: An empirical analysis." Journal of Financial Economics 110.2 (2013): 478-502.

Christensen, Bent J., Rasmus Lentz, Dale T. Mortensen, George R. Neumann, and Axel Werwatz. "On-the-Job Search and the Wage Distribution." Journal of Labor Economics 23-1 (2005): 31-58.

Couch, Kenneth A., and Dana W. Placzek. "Earnings losses of displaced workers revisited." American Economic Review 100.1 (2010):572-589.

Davis, Steven J., John Haltiwanger, Kyle Handley, Ron Jarmin, Josh Lerner, and Javier Miranda. "Private Equity, Jobs, and Productivity." American Economic Review 104.12 (2014): 39563990.

Dechow, Patricia M., Weili Ge, Chad R. Larson, and Richard G. Sloan. "Predicting material accounting misstatements." Contemporary Accounting Research 28.1 (2011): 17-82.

Dechow, Patricia, Weili Ge, and Catherine Schrand. "Understanding earnings quality: A review of the proxies, their determinants and their consequences." Journal of Accounting and Economics 50.2-3 (2010) 344-401.

Desai, Hemang, Chris E. Hogan, and Michael S. Wilkins. "The reputation penalty for aggressive accounting: Earnings restatements and management turnover." The Accounting Review 81.1 (2006): 83-112.

Dyck, Alexander, Adair Morse, and Luigi Zingales. "How pervasive is corporate fraud?" Working paper (2013).

Erickson, Merle, Michelle Hanlon, and Edward L. Maydew. "How Much Will Firms Pay for Earnings That Do Not Exist? Evidence of Taxes Paid on Allegedly Fraudulent Earnings." The Accounting Review 79.2 (2004): 387-408.

Falato, Antonio, and Nellie Liang. "Do creditor rights increase employment risk? Evidence from loan covenants." The Journal of Finance 71.6 (2016): 2545-2590. 
Fama, Eugene F. "Agency problems and the theory of the firm." Journal of Political Economy 88.2 (1980): 288-307.

Farber, David B. "Restoring Trust after Fraud: Does Corporate Governance Matter?" The Accounting Review 80.2 (2005): 539-561.

Feroz, Ehsan H., Kyungjoo Park, and Victor S. Pastena. "The financial and market effects of the SEC's accounting and auditing enforcement releases." Journal of Accounting Research 29 Supplement (1991): 107-142.

Flaaen, Aaron, Matthew D. Shapiro, and Issac Sorkin. "Reconsidering the Consequences of Worker Displacements: Firm versus Worker Perspective." American Economic Journal: Macroeconomics, forthcoming.

Gibbons, Robert, and Lawrence F. Katz. "Layoffs and Lemons." Journal of Labor Economics 9.4 (1991): 351-380.

Giroud, Xavier, and Holger M. Mueller. "Firm leverage, consumer demand, and employment losses during the Great Recession." The Quarterly Journal of Economics 132.1 (2017): 271316.

Graham, John R., Hyunseob Kim, Si Li, and Jiaping Qiu. "Employee Costs of Corporate Bankruptcy." Working paper (2016).

Groysberg, Boris, Eric Lin, and George Serafeim. "Does Financial Misconduct Affect the Future Compensation of Alumni Managers?" Working paper (2017).

Guiso, Luigi, Luigi Pistaferri, and Fabiano Schivardi. "Insurance within the Firm." Journal of Political Economy 113.5 (2005): 1054-1087.

Ham, Charles, Mark Lang, Nicholas Seybert, and Sean Wang. "CFO Narcissism and Financial Reporting Quality.” Journal of Accounting Research 55.5 (2017): 1089-1135.

Hass, Lars Helge, Paul Hribar, Fani Kalogirou. "The disciplining effect of labor mobility: Evidence from real earnings management." Working paper (2018).

Holzman, Eric R., Brian P. Miller, and Brian M. Williams. "The Local Spillover Effect of Corporate Accounting Misconduct: Evidence from City Crime Rates." Working paper (2019).

Hummels, David, Rasmus Jorgensen, Jakob Munch, and Chong Xiang. "The Wage Effects of Offshoring: Evidence from Danish Matched Worker-Firm Data." American Economic Review 104.6 (2014): 1597-1629.

Hyatt, Henry, and Ericka McEntarfer. "Job-to-Job Flows in the Great Recession." American Economic Review: Papers \& Proceedings 102.3 (2012): 580-583.

Jacobson, Louis S., Robert J. LaLonde, and Daniel G. Sullivan. "Earnings Losses of Displaced Workers." American Economic Review 83.4 (1993): 685-709.

John, Kose, Larry HP Lang, and Jeffry Netter. "The voluntary restructuring of large firms in response to performance decline." The Journal of Finance 47.3 (1992): 891-917.

Jovanovic, Boyan. "Job matching and the theory of turnover." Journal of Political Economy 87.5, Part 1 (1979): 972-990. 
Karpoff, Jonathan M., Allison Koester, D. Scott Lee, and Gerald S. Martin. "Proxies and Databases in Financial Misconduct Research.” The Accounting Review 92.6 (2017): 129-163.

Karpoff, Jonathan M., D. Scott Lee, and Gerald S. Martin. "The consequences to managers for financial misrepresentation.” Journal of Financial Economics 88.2 (2008a): 193.215

Karpoff, Jonathan M., D. Scott Lee, and Gerald S. Martin. "The cost to firms of cooking the books." Journal of Financial and Quantitative Analysis 43.3 (2008b): 581-611.

Kedia, Simi, and Thomas Philippon. "The Economics of Fraudulent Accounting." The Review of Financial Studies 22.6 (2009): 2169-2199.

Kedia, Simi, and Shiva Rajgopal. "Do the SEC's enforcement preferences affect corporate misconduct?” Journal of Accounting and Economics 51.3 (2011): 259-278.

Lazear, Edward P. "Firm-Specific Human Capital: A Skill-Weights Approach." Journal of Political Economy 117.5 (2009): 914-940.

Lee, Kyeong Hun, David C. Mauer, and Emma Qianying Xu. "Human capital relatedness and mergers and acquisitions." Journal of Financial Economics 129.1 (2018): 111-135.

Li, Valerie. “Do False Financial Statements Distort Peer Firms' Decisions?” The Accounting Review 91.1 (2016): 251-278.

Liberto, Jennifer. "House passes bipartisan bill aimed at start-ups.” CNN Money (2012).

Leuz, Christian. "Evidence-Based Policymaking: Promise, Challenges and Opportunities for Accounting and Financial Markets Research." Working paper (2018).

Makridis, Christos and Yuqing Zhou. "Firm Reputation Following Financial Misconduct: Evidence from Employee Ratings. Working paper (2019).

McNichols, Maureen F., and Stephen R. Stubben. "Does Earnings Management Affect Firms' Investment Decisions?” The Accounting Review 83.6 (2008): 1571-1603.

Mincer, Jacob. "Wage Changes in Job Changes.” Working paper at NBER (1986).

Moretti, Enrico. "Local Labor Markets.” Handbook of Labor Economics 4 (2011): 1,237-1,313.

Noguchi, Yuki. “WorldCom Lays Off 17,000 Workers.” The Washington Post June 29, 2002.

Ouimet, Paige, and Rebecca Zarutskie. "Who works for startups? The relation between firm age, employee age, and growth.” Journal of Financial Economics 112.3 (2014): 386-407.

Roberts, Michael R., and Toni M. Whited. "Chapter 7: Endogeneity in Empirical Corporate Finance." Handbook of the Economics of Finance Vol. 2. Elsevier, 2013. 493-572.

Sadka, Gil. "The economic consequences of accounting fraud in product markets: Theory and a case from the US telecommunications industry (WorldCom)." American Law and Economics Review 8.3 (2006): 439-475.

Schrand, Catherine M., and Sarah LC Zechman. "Executive overconfidence and the slippery slope to financial misreporting." Journal of Accounting and Economics 53.1-2 (2012): 311-329.

Securities and Exchange Commission (SEC) "SEC Charges Kenneth L. Lay, Enron's Former Chairman and Chief Executive Officer, with Fraud and Insider Trading." AAER No. 2051 July 8, 2004. Available at: https://www.sec.gov/litigation/litreleases/lr18776.htm. 
Srinivasan, Suraj. "Consequences of Financial Reporting Failure for outside Directors: Evidence from Accounting Restatements and Audit Committee Members." Journal of Accounting Research 43.2 (2005): 291-334.

Topel, Robert. "Specific Capital, Mobility, and Wages: Wages Rise with Job Seniority." Journal of Political Economy 99.1 (1991): 145-176.

Walker, W. Reed. "The transitional costs of sectoral reallocation: Evidence from the clean air act and the workforce." The Quarterly Journal of Economics 128.4 (2013): 1787-1835.

Whitaker, Richard B. "The early stages of financial distress." Journal of Economics and Finance 23.2 (1999): 123-132. 


\section{Appendix Table A: Variable Definitions}

\begin{tabular}{|c|c|c|}
\hline Variable & Definition & $\begin{array}{l}\text { Data } \\
\text { Source }\end{array}$ \\
\hline \multicolumn{3}{|c|}{ Dependent Variables } \\
\hline $\begin{array}{l}\text { Annual Real } \\
\text { Wages }\end{array}$ & $\begin{array}{l}\text { Annual earnings from a primary employer divided by the } \\
\text { Consumer Price Index (2010) }\end{array}$ & LEHD \\
\hline $\begin{array}{l}\text { Fraud Firm } \\
\text { Indicator }\end{array}$ & $\begin{array}{l}\text { Companies that are identified as accounting-fraud firms by the } \\
\text { AAER from } 1970 \text { through } 2014\end{array}$ & $\begin{array}{l}\text { CFRM, } \\
\text { AAERs }\end{array}$ \\
\hline \multicolumn{3}{|c|}{ Independent Variables } \\
\hline $\begin{array}{l}\text { Fraud } \\
\text { Indicator }\end{array}$ & $\begin{array}{l}\text { Workers who are at fraud firms as either an Existing Employee or } \\
\text { a New Employee }\end{array}$ & LEHD \\
\hline $\operatorname{Pre}(t-p)$ & $\begin{array}{l}1 \text { if year } \tau \text { falls } p(=1,2,3,4) \text { year(s) before a fraud firm engaged in } \\
\text { accounting fraud; } 0 \text { otherwise }\end{array}$ & $\begin{array}{l}\text { CFRM, } \\
\text { AAERs }\end{array}$ \\
\hline $\operatorname{Fraud}(t+p)$ & $\begin{array}{l}1 \text { if year } \tau \text { falls } \mathrm{p}(=0,1,2) \text { year(s) after the first year of accounting } \\
\text { fraud and if a fraud firm engaged in accounting fraud in year } \tau ; 0 \\
\text { otherwise. For long-lasting frauds, we normalize this period to a } \\
\text { maximum of three years by indicating additional fraud years as } \\
\text { Fraud }(t+2)\end{array}$ & $\begin{array}{l}\text { CFRM, } \\
\text { AAERs }\end{array}$ \\
\hline $\operatorname{Post}(t+p)$ & $\begin{array}{l}1 \text { if year } \tau \text { falls } p(=3,4,5,6,7,8) \text { year(s) after the first year of } \\
\text { accounting fraud, normalized so that } p=3 \text { is the year after an } \\
\text { accounting fraud is revealed; } 0 \text { otherwise }\end{array}$ & $\begin{array}{l}\text { CFRM, } \\
\text { AAERs }\end{array}$ \\
\hline
\end{tabular}

\begin{tabular}{|c|c|c|}
\hline \multicolumn{3}{|l|}{ Sample Splits } \\
\hline $\begin{array}{l}\text { Existing } \\
\text { Employee }\end{array}$ & $\begin{array}{l}\text { Worker at a fraud or control firm for the last two years before a } \\
\text { fraud firm engaged in accounting fraud, Pret-2 and Pret-1 }\end{array}$ & LEHD \\
\hline $\begin{array}{l}\text { New } \\
\text { Employee }\end{array}$ & $\begin{array}{l}\text { Worker newly hired in the first year of a fraud period, Fraudt, by a } \\
\text { fraud or control firm }\end{array}$ & LEHD \\
\hline $\begin{array}{l}\text { Thin / Thick } \\
\text { Labor } \\
\text { Markets }\end{array}$ & $\begin{array}{l}\text { Thin local labor markets have fewer industry-specific employers } \\
\text { than the median of the number of industry-specific employers in } \\
\text { local labor markets }\end{array}$ & LEHD \\
\hline $\begin{array}{l}\text { Bankruptcy } \\
\text { Fraud Firms }\end{array}$ & $\begin{array}{l}\text { Fraud firms that declare bankruptcy within three years after frauds } \\
\text { are revealed }\end{array}$ & BRD \\
\hline $\begin{array}{l}\text { Stayer / } \\
\text { Leaver }\end{array}$ & $\begin{array}{l}\text { Stayer if an employee continues to work for the fraud or control } \\
\text { firm three years after the accounting fraud is revealed, Post } t_{t+6} \\
\text { and/or later; leaver otherwise }\end{array}$ & LEHD \\
\hline $\begin{array}{l}\text { Early / Late } \\
\text { Leaver }\end{array}$ & $\begin{array}{l}\text { Early leaver if an employee left the fraud or control firm in the } \\
\text { first year of accounting fraud, Fraudi late leaver if the fraud or } \\
\text { control firm in any other year of accounting fraud or within two } \\
\text { years after accounting fraud is revealed, Fraud } t_{t+1} \text { through Post } t_{t+5}\end{array}$ & LEHD \\
\hline Top $10 \%$ & $\begin{array}{l}\text { Workers earn real wages more than or equal to the } 10 \text { percentile } \\
\text { real wage in the wage distribution }\end{array}$ & LEHD \\
\hline Bottom 90\% & $\begin{array}{l}\text { Workers earn real wages less than the } 10 \text { percentile real wage in } \\
\text { the wage distribution }\end{array}$ & LEHD \\
\hline
\end{tabular}


Appendix Table A: Variable Definitions (continued)

\begin{tabular}{|c|c|c|}
\hline Variable & Definition & $\begin{array}{l}\text { Data } \\
\text { Source }\end{array}$ \\
\hline \multicolumn{3}{|c|}{ Firm Controls } \\
\hline Size & Natural log of total assets (data6) & Compustat \\
\hline $\begin{array}{l}\text { Return on } \\
\text { Assets }\end{array}$ & $\begin{array}{l}\text { Operating income after depreciation (data178) divided by total } \\
\text { assets (data6) }\end{array}$ & Compustat \\
\hline Leverage & $\begin{array}{l}\text { The ratio of total debt (data9+data34) to market value of assets, } \\
\text { which is calculated by multiplying the number of shares } \\
\text { outstanding (data25) by the stock price (data199) and by adding } \\
\text { total debt (data9+data34) to it }\end{array}$ & Compustat \\
\hline Tobin's $Q$ & $\begin{array}{l}\text { Market value of assets divided by book value of assets (data6), } \\
\text { where market value of assets is calculated by } \\
\text { (data25*data199+data9+data34) }\end{array}$ & Compustat \\
\hline $\begin{array}{l}\text { Employee } \\
\text { Growth }\end{array}$ & $\begin{array}{l}\text { Natural log of this year's employment minus natural log of last } \\
\text { year's employment }\end{array}$ & LBD \\
\hline $\begin{array}{l}\text { Avg. Annual } \\
\text { Real Wages }\end{array}$ & Total wage bill divided by employment & LBD \\
\hline \multicolumn{3}{|c|}{ Employee Controls } \\
\hline Age & Age of an employee in an event year of accounting fraud & LEHD \\
\hline Education & $\begin{array}{l}\text { Four levels of education are transformed into numerical values by } \\
\text { using the highest number of years in each category: less than high } \\
\text { school (1-8), high school or equivalent, no college ( } 9 \text { ), some } \\
\text { college or associate degree (10-12), and bachelor's degree or } \\
\text { advanced degree (13-16) }\end{array}$ & LEHD \\
\hline Experience & Age of a worker in year $t$ minus education minus 6 & LEHD \\
\hline Female & 1 if a person is female; 0 otherwise & LEHD \\
\hline
\end{tabular}




\section{Appendix Table B: Probit Model}

This table shows the results of a probit model estimating a propensity score to engage in accounting fraud. Accountingfraud firms are identified by the AAER. Fraud firms are included in sample firms in the year prior to accounting fraud, $\operatorname{Pre}(t-1)$. Non-fraud firms are included in sample firms if they operate businesses in the same industry as one of fraud firms in the year prior to accounting fraud. The sample period is from 1991 to 2008. Appendix Table A defines variables. Statistical significance at the $10 \%, 5 \%$, and $1 \%$ levels is indicated by $* * *$, and $* * *$, respectively. Number of observations are rounded to comply with disclosure requirements of the U.S. Census Bureau.

(1)

Dependent Variable: Fraud-Firm Indicator

Size $\quad 0.098 * * *$

(0.018)

Return on Assets

$0.255^{*}$

$(0.153)$

Leverage

$-0.138$

Tobin's $Q$

$(0.137)$

$0.015^{* *}$

Employee Growth

$(0.007)$

Employee Growth

$0.215^{* * *}$

Ln(Avg. Annual Real Wages)

$(0.076)$

0.020

$(0.072)$

Observations

16,000

Chi-squared

144.2

Pseudo R-squared

0.0777 


\section{Table 1. Fraud Firms}

\section{Panel A. Comparison of Sample Fraud and Matched Control Firms}

This table compares fraud firms' to control firms' characteristics in the year prior to accounting fraud, Pre(t-1). Accounting-fraud firms are identified by the AAER. Control firms are matched to fraud firms based on a propensity score estimated in Appendix Table B. The sample period is from 1991 to 2008. Appendix Table A defines variables. Statistical significance at the $10 \%, 5 \%$, and $1 \%$ levels is indicated by *,**, and ***, respectively. Significance below these conventional levels is indicated with "ns." Number of observations are rounded to comply with disclosure requirements of the U.S. Census Bureau.

\begin{tabular}{|c|c|c|c|c|}
\hline & \multirow[t]{2}{*}{$\begin{array}{l}(1) \\
\text { Fraud } \\
\text { Firms }\end{array}$} & \multirow[t]{2}{*}{$\begin{array}{l}(2) \\
\text { Non-Fraud } \\
\text { Firms }\end{array}$} & \multicolumn{2}{|c|}{$\begin{array}{c}\text { (3) } \\
\text { T Tests of Differences } \\
\text { (Fraud minus Non-Fraud) }\end{array}$} \\
\hline & & & Difference & Significance \\
\hline Size & 6.372 & 6.248 & 0.125 & ns \\
\hline Assets $(\$ M)$ & 5,328 & 3,998 & 1,330 & $\mathrm{~ns}$ \\
\hline Return on Assets & .0693 & .0713 & -0.0020 & ns \\
\hline Leverage & .2408 & .2173 & 0.0235 & ns \\
\hline Tobin's $Q$ & 2.458 & 2.471 & -0.013 & ns \\
\hline Employee growth & .1672 & .1665 & 0.0007 & ns \\
\hline Avg. Annual Real Wages & 53.72 & 55.17 & -1.45 & ns \\
\hline Observations & 200 & 200 & & \\
\hline
\end{tabular}




\section{Table 1. Fraud Firms}

\section{Panel B. Comparative Descriptive Statistics on Sample and All Fraud Firms}

This table compares statistics on samples of fraud firms. Column (1) indicates descriptive statistics of sample fraud companies, and column (2) indicates descriptive statistics of all fraud firms. Column (3) indicates signed differences between columns 1 and 2. Fraud firms are identified by the AAER. All fraud companies are required to have relevant Compustat data. They engaged in accounting fraud from 1970 to 2014. Sample fraud companies are required to have relevant Compustat, LBD, and LEHD data. They engaged in accounting fraud from 1991 to 2008. Appendix Table A defines variables. Number of observations are rounded to comply with disclosure requirements of the U.S. Census Bureau.

\begin{tabular}{lcc}
\hline & $(1)$ & $(2)$ \\
& Sample Fraud & All Fraud \\
& Firms & Firms \\
\hline Size & 6.372 & 5.423 \\
Assets $(\$ M)$ & 5,328 & 4,102 \\
Return on Assets & .0693 & .0157 \\
Leverage & .2408 & .2552 \\
Tobin's $Q$ & 2.458 & 2.838 \\
\hline Observations & 200 & 500 \\
\hline
\end{tabular}




\section{Table 2. Descriptive Statistics for Employees of Fraud and Control Firms}

This table shows differences for averages of employees at fraud and control firms. Accounting-fraud firms in the sample commit financial misrepresentation from 1991 to 2008 according to the AAER. Fraud firms are matched with control firms using a propensity score estimated in Appendix Table B. Appendix Table A defines variables. Statistical significance at the $10 \%, 5 \%$, and $1 \%$ levels is indicated by $* * *$, and $* * *$, respectively. Significance below these conventional levels is indicated with "ns." Number of observations are rounded to comply with disclosure requirements of the U.S. Census Bureau.

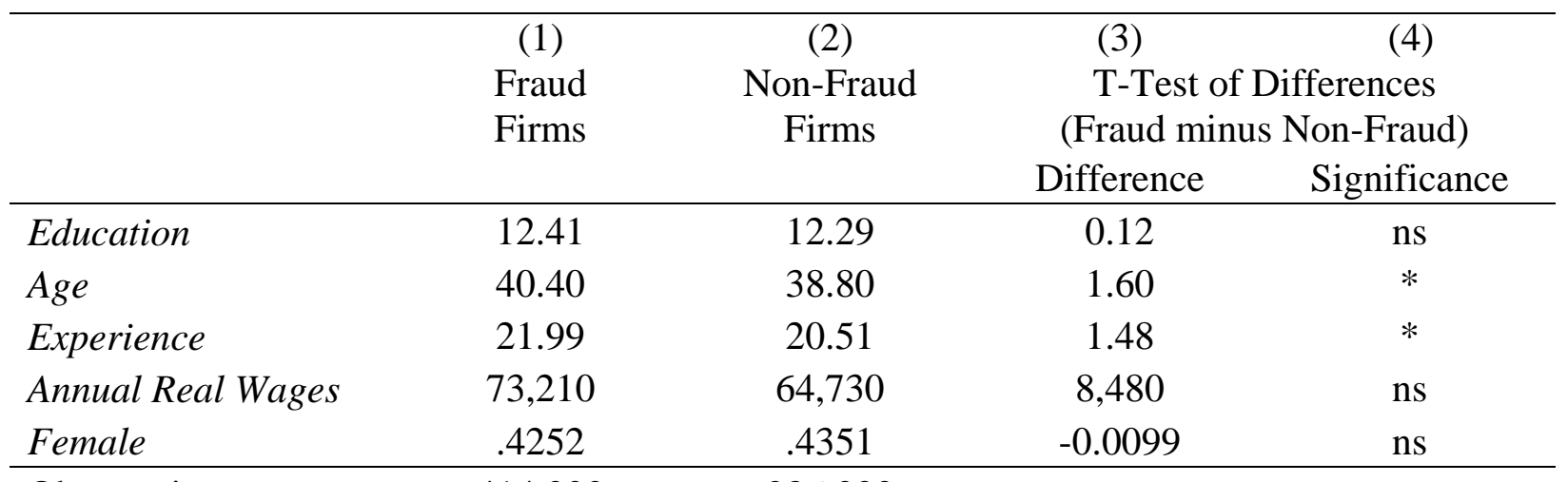




\section{Table 3. Dynamics of Earnings for Fraud Firm Employees}

This table reports estimates from OLS regression analyses estimating equation (2): estimates for wage effects at fraud firms in the by-event-time years. Accounting-fraud firms in the sample commit financial misrepresentation from 1991 to 2008 according to the AAER. Appendix Table A defines variables. Standard errors are in parentheses and calculated with clustering by pre-fraud employer (i.e., fraud firm or matched control firm). Statistical significance at the $10 \%$, $5 \%$, and $1 \%$ levels is indicated by $* * *$, and $* * *$, respectively. Number of observations are rounded to comply with disclosure requirements of the U.S. Census Bureau.

\begin{tabular}{|c|c|c|c|}
\hline $\begin{array}{l}\text { Dependent Variable }= \\
\text { Ln(Annual Real Wages })\end{array}$ & $\begin{array}{c}\text { (1) } \\
\text { Year } \\
\text { Effects }\end{array}$ & $\begin{array}{c}(2) \\
\text { Year- Industry } \\
\text { Effects }\end{array}$ & $\begin{array}{c}(3) \\
\text { Year- Industry- } \\
\text { County } \\
\text { Effects }\end{array}$ \\
\hline Pre $(t-4) \times$ Fraud Ind. & $\begin{array}{l}-0.045 \\
(0.038)\end{array}$ & $\begin{array}{l}-0.011 \\
(0.033)\end{array}$ & $\begin{array}{l}-0.008 \\
(0.015)\end{array}$ \\
\hline $\operatorname{Pre}(t-3) \times$ Fraud Ind & $\begin{array}{l}-0.078 * \\
(0.047)\end{array}$ & $\begin{array}{l}-0.025 \\
(0.037)\end{array}$ & $\begin{array}{l}-0.0093 \\
(0.021)\end{array}$ \\
\hline $\operatorname{Pre}(t-2) \times$ Fraud $I n d$. & $\begin{array}{l}-0.083^{*} \\
(0.044)\end{array}$ & $\begin{array}{l}-0.041 \\
(0.034)\end{array}$ & $\begin{array}{c}0.032 \\
(0.027)\end{array}$ \\
\hline $\operatorname{Pre}(t-1) \times$ Fraud Ind & $\begin{array}{l}-0.080 * \\
(0.048)\end{array}$ & $\begin{array}{l}-0.061 * \\
(0.033)\end{array}$ & $\begin{array}{c}0.017 \\
(0.031)\end{array}$ \\
\hline Fraud $(t) \times$ Fraud Ind & $\begin{array}{l}-0.168 * * \\
(0.073)\end{array}$ & $\begin{array}{l}-0.124 * * * \\
(0.048)\end{array}$ & $\begin{array}{l}-0.066 * * \\
(0.031)\end{array}$ \\
\hline Fraud $(t+1) \times$ Fraud $I n d$ & $\begin{array}{l}-0.149 * * * \\
(0.057)\end{array}$ & $\begin{array}{l}-0.120 * * \\
(0.047)\end{array}$ & $\begin{array}{l}-0.078 * * \\
(0.037)\end{array}$ \\
\hline $\operatorname{Fraud}(t+2) \times$ Fraud Ind. & $\begin{array}{l}-0.192 * * * \\
(0.070)\end{array}$ & $\begin{array}{l}-0.146^{* * *} \\
(0.051)\end{array}$ & $\begin{array}{l}-0.093 * * * \\
(0.032)\end{array}$ \\
\hline $\operatorname{Post}(t+3) \times$ Fraud Ind & $\begin{array}{l}-0.137 * * \\
(0.067)\end{array}$ & $\begin{array}{l}-0.114 * * \\
(0.045)\end{array}$ & $\begin{array}{l}-0.077 * * \\
(0.030)\end{array}$ \\
\hline $\operatorname{Post}(t+4) \times$ Fraud Ind & $\begin{array}{l}-0.160 * * \\
(0.065)\end{array}$ & $\begin{array}{l}-0.129 * * * \\
(0.047)\end{array}$ & $\begin{array}{l}-0.080 * * \\
(0.035)\end{array}$ \\
\hline $\operatorname{Post}(t+5) \times$ Fraud Ind & $\begin{array}{l}-0.194 * * * \\
(0.074)\end{array}$ & $\begin{array}{l}-0.160 * * * \\
(0.054)\end{array}$ & $\begin{array}{l}-0.110 * * * \\
(0.042)\end{array}$ \\
\hline Post $(t+6) \times$ Fraud Ind. & $\begin{array}{l}-0.197 * * \\
(0.084)\end{array}$ & $\begin{array}{l}-0.159 * * * \\
(0.055)\end{array}$ & $\begin{array}{l}-0.090 * * \\
(0.042)\end{array}$ \\
\hline Post $(t+7) \times$ Fraud Ind & $\begin{array}{c}-0.173^{*} \\
(0.088)\end{array}$ & $\begin{array}{l}-0.147 * * \\
(0.058)\end{array}$ & $\begin{array}{l}-0.098 * * \\
(0.042)\end{array}$ \\
\hline Post $(t+8) \times$ Fraud Ind & $\begin{array}{l}-0.228 * * \\
(0.114)\end{array}$ & $\begin{array}{l}-0.197 * * \\
(0.078)\end{array}$ & $\begin{array}{l}-0.128 * * * \\
(0.045)\end{array}$ \\
\hline Controls and main effects & Yes & Yes & Yes \\
\hline Fixed Effects & $\begin{array}{l}\text { Year, } \\
\text { Worker }\end{array}$ & $\begin{array}{c}\text { Year } \times \\
\text { Industry, } \\
\text { Worker }\end{array}$ & $\begin{array}{c}\text { Year } \times \\
\text { Industry } \times \\
\text { County, } \\
\text { Worker }\end{array}$ \\
\hline Observations & $9,062,000$ & $9,062,000$ & $9,038,000$ \\
\hline R-squared & 0.550 & 0.586 & 0.634 \\
\hline
\end{tabular}




\section{Table 4. Dynamics of Displacement for Employees}

This table shows averages and differences of employee retention at fraud and matched control firms. Accountingfraud firms in the sample commit financial misrepresentation from 1991 to 2008 according to the AAER. Fraud firms are matched with control firms using a propensity score estimated in Appendix Table B. These indicator variables equal one if an employee stays at the firm, in the industry, or in the county and equal zero otherwise. Specifically, if we observe the employee with their next job at the same firm, or in the same industry, or in the same county as the firm where the employee is employed during periods $\operatorname{Pr}_{t-1}$ and $\operatorname{Pre}_{t-2}$, then the indicator variable equals one. We calculate these indicators for periods Fraud(t), Post $(t+5)$, and Post $(t+8)$. Statistical significance at the 10\%, 5\%, and $1 \%$ levels is indicated by $*, * *$, and $* * *$, respectively. Significance below these conventional levels is indicated with "ns." Number of observations are rounded to comply with disclosure requirements of the U.S. Census Bureau.

\begin{tabular}{|c|c|c|c|c|}
\hline & \multirow[t]{2}{*}{$\begin{array}{l}(1) \\
\text { Fraud } \\
\text { Firms }\end{array}$} & \multirow[t]{2}{*}{$\begin{array}{l}(2) \\
\text { Non-Fraud } \\
\text { Firms }\end{array}$} & \multicolumn{2}{|c|}{$\begin{array}{l}\text { (3) } \\
\text { T-Test of Differences } \\
\text { (Fraud minus Non-Fraud) }\end{array}$} \\
\hline & & & Sign & Significance \\
\hline \multicolumn{5}{|l|}{$\operatorname{Fraud}(t)$} \\
\hline$\%$ Stay at Firm & $87.3 \%$ & $90.8 \%$ & $-3.5 \%$ & $* *$ \\
\hline$\%$ Stay in Industry & $85.5 \%$ & $90.6 \%$ & $-5.1 \%$ & ns \\
\hline$\%$ Stay in County & $88.5 \%$ & $88.7 \%$ & $-0.2 \%$ & ns \\
\hline \multicolumn{5}{|l|}{$\operatorname{Post}(t+5)$} \\
\hline$\%$ Stay at Firm & $37.6 \%$ & $54.8 \%$ & $-17.2 \%$ & $* * *$ \\
\hline$\%$ Stay in Industry & $44.6 \%$ & $59.1 \%$ & $-14.5 \%$ & $* * *$ \\
\hline \%Stay in County & $50.7 \%$ & $63.1 \%$ & $-12.4 \%$ & $* * *$ \\
\hline \multicolumn{5}{|l|}{$\operatorname{Post}(t+8)$} \\
\hline$\%$ Stay at Firm & $26.1 \%$ & $41.0 \%$ & $-14.9 \%$ & $* *$ \\
\hline$\%$ Stay in Industry & $33.3 \%$ & $46.5 \%$ & $-13.2 \%$ & $* *$ \\
\hline$\%$ Stay in County & $39.3 \%$ & $50.5 \%$ & $-11.2 \%$ & $* * *$ \\
\hline Observations & 414,000 & 286,000 & & \\
\hline
\end{tabular}




\section{Table 5. Robustness: Alternative Matching}

This table reports estimates from OLS regression analyses estimating equation (2): estimates for wage effects at fraud firms in the by-event-time years. We use a separate sample of newly hired employees that first receive wages at the fraud or matched control firm in period $\operatorname{Fraud}(t)$, i.e., the first year of the fraud. Accounting-fraud firms in the sample commit financial misrepresentation from 1991 to 2008 according to the AAER. Appendix Table A defines variables. Standard errors are in parentheses and calculated with clustering by fraud-period employer (i.e., fraud firm or matched control firm). Statistical significance at the $10 \%, 5 \%$, and $1 \%$ levels is indicated by $* * *$, and $* * *$, respectively. Number of observations are rounded to comply with disclosure requirements of the U.S. Census Bureau.

(1)

Fraud Period,

Matching:

Dependent Variable $=$ Ln(Annual Real Wages)

\begin{tabular}{|c|c|c|}
\hline $\operatorname{Pre}(t-4) \times$ Fraud Ind & $\begin{array}{c}0.021 \\
(0.014)\end{array}$ & $\begin{array}{c}0.022 \\
(0.018)\end{array}$ \\
\hline $\operatorname{Pre}(t-3) \times$ Fraud Ind. & $\begin{array}{c}(0.014) \\
0.013\end{array}$ & $\begin{array}{c}(0.018) \\
0.024\end{array}$ \\
\hline 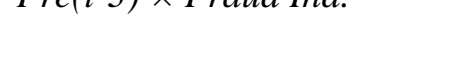 & $\begin{array}{l}0.013 \\
(0.020)\end{array}$ & $\begin{array}{c}0.024 \\
(0.017)\end{array}$ \\
\hline $\operatorname{Pre}(t-2) \times$ Fraud Ind . & $\begin{array}{c}0.037 \\
(0.026)\end{array}$ & $\begin{array}{l}0.074 * * \\
(0.034)\end{array}$ \\
\hline Pre $(t-1) \times$ Fraud Ind & $\begin{array}{c}0.013 \\
(0.032)\end{array}$ & $\begin{array}{c}0.099 \\
(0.067)\end{array}$ \\
\hline Fraud $(t) \times$ Fraud Ind & $\begin{array}{l}-0.062^{* *} \\
(0.029)\end{array}$ & $\begin{array}{l}-0.019 \\
(0.022)\end{array}$ \\
\hline $\operatorname{Fraud}(t+1) \times$ Fraud Ind & $\begin{array}{l}-0.057 \\
(0.038)\end{array}$ & $\begin{array}{l}-0.028 \\
(0.032)\end{array}$ \\
\hline Fraud $(t+2) \times$ Fraud Ind & $\begin{array}{l}-0.099 * * \\
(0.039)\end{array}$ & $\begin{array}{l}-0.044^{*} \\
(0.024)\end{array}$ \\
\hline Post $(t+3) \times$ Fraud Ind & $\begin{array}{l}-0.077 * * \\
(0.032)\end{array}$ & $\begin{array}{l}-0.021 \\
(0.022)\end{array}$ \\
\hline Post $(t+4) \times$ Fraud Ind & $\begin{array}{l}-0.095^{* *} \\
(0.037)\end{array}$ & $\begin{array}{l}-0.042 \\
(0.034)\end{array}$ \\
\hline Post $(t+5) \times$ Fraud Ind & $\begin{array}{l}-0.124 * * * \\
(0.042)\end{array}$ & $\begin{array}{l}-0.099^{* *} \\
(0.045)\end{array}$ \\
\hline Post $(t+6) \times$ Fraud Ind & $\begin{array}{l}-0.120^{* * *} \\
(0.044)\end{array}$ & $\begin{array}{l}-0.029 \\
(0.039)\end{array}$ \\
\hline Post $(t+7) \times$ Fraud Ind & $\begin{array}{l}-0.128^{* * *} \\
(0.045)\end{array}$ & $\begin{array}{l}-0.021 \\
(0.039)\end{array}$ \\
\hline Post $(t+8) \times$ Fraud Ind & $\begin{array}{l}-0.147^{* * * *} \\
(0.047)\end{array}$ & $\begin{array}{l}-0.035 \\
(0.038)\end{array}$ \\
\hline Controls and main effects & Yes & Yes \\
\hline Fixed Effects & $\begin{array}{l}\text { Year } \times \text { Industry } \times \\
\text { County, Worker }\end{array}$ & $\begin{array}{c}\text { Year } \times \text { Industry } \times \\
\text { County, Worker }\end{array}$ \\
\hline Observations & $8,761,000$ & $2,602,000$ \\
\hline R-squared & 0.636 & 0.674 \\
\hline
\end{tabular}




\section{Table 6. Employee Earnings and Market and Firm Heterogeneity}

This table reports estimates from OLS regression analyses estimating equation (2): estimates for wage effects at fraud firms in the by-event-time years. We divide the sample into "thick" and "thin" markets that have above and below median, respectively, within-industry employers in the same county. We present results for "thick" ("thin") markets in columns (1) (in column (2)). We divide the sample into bankruptcy and non-bankruptcy fraud firms along with their matched pair. Results for firms that ultimately (do not) go into bankrupt are present in column (3) (in column (4)). We present estimates from specifications with Year $\times$ Industry $\times$ County effects throughout. Appendix Table A defines variables. Standard errors are in parentheses and calculated with clustering by pre-fraud employer (i.e., fraud firm or matched control firm). Statistical significance at the $10 \%, 5 \%$, and $1 \%$ levels is indicated by *, **, and ***, respectively. Number of observations are rounded to comply with disclosure requirements of the U.S. Census Bureau.

\begin{tabular}{|c|c|c|c|c|}
\hline & (1) & (2) & (3) & (4) \\
\hline $\begin{array}{l}\text { Dependent Variable }= \\
\text { Ln(Annual Real Wages })\end{array}$ & $\begin{array}{l}\text { Thick } \\
\text { Markets }\end{array}$ & $\begin{array}{l}\text { Thin } \\
\text { Markets }\end{array}$ & $\begin{array}{l}\text { Bankruptcy } \\
\text { Fraud Firms }\end{array}$ & $\begin{array}{l}\text { Non-Bankruptcy } \\
\text { Fraud Firms }\end{array}$ \\
\hline Pre $(t-4) \times$ Fraud Ind & $\begin{array}{c}0.005 \\
(0.017)\end{array}$ & $\begin{array}{l}-0.062 * * \\
(0.027)\end{array}$ & $\begin{array}{c}0.018 \\
(0.051)\end{array}$ & $\begin{array}{l}-0.012 \\
(0.015)\end{array}$ \\
\hline Pre $(t-3) \times$ Fraud Ind & $\begin{array}{c}0.016 \\
(0.028)\end{array}$ & $\begin{array}{l}-0.066 * * * \\
(0.025)\end{array}$ & $\begin{array}{c}0.013 \\
(0.090)\end{array}$ & $\begin{array}{l}-0.013 \\
(0.021)\end{array}$ \\
\hline $\operatorname{Pre}(t-2) \times$ Fraud Ind. & $\begin{array}{l}0.061 * \\
(0.033)\end{array}$ & $\begin{array}{l}-0.044 \\
(0.033)\end{array}$ & $\begin{array}{l}-0.061 \\
(0.092)\end{array}$ & $\begin{array}{c}0.031 \\
(0.028)\end{array}$ \\
\hline $\operatorname{Pre}(t-1) \times$ Fraud Ind. & $\begin{array}{l}0.081 * * \\
(0.036)\end{array}$ & $\begin{array}{l}-0.110^{* * * *} \\
(0.039)\end{array}$ & $\begin{array}{l}0.008 \\
(0.070)\end{array}$ & $\begin{array}{c}0.019 \\
(0.033)\end{array}$ \\
\hline Fraud $(t) \times$ Fraud Ind & $\begin{array}{l}-0.007 \\
(0.036)\end{array}$ & $\begin{array}{l}-0.171 * * * \\
(0.046)\end{array}$ & $\begin{array}{l}-0.031 \\
(0.112)\end{array}$ & $\begin{array}{l}-0.062^{*} \\
(0.032)\end{array}$ \\
\hline $\operatorname{Fraud}(t+1) \times$ Fraud Ind. & $\begin{array}{l}-0.013 \\
(0.039)\end{array}$ & $\begin{array}{l}-0.185^{* * * *} \\
(0.050)\end{array}$ & $\begin{array}{l}-0.175 * * \\
(0.083)\end{array}$ & $\begin{array}{l}-0.072 * \\
(0.038)\end{array}$ \\
\hline Fraud $(t+2) \times$ Fraud $I n d$ & $\begin{array}{l}-0.060 \\
(0.038)\end{array}$ & $\begin{array}{l}-0.159 * * * \\
(0.049)\end{array}$ & $\begin{array}{l}-0.188 * * \\
(0.085)\end{array}$ & $\begin{array}{l}-0.088^{* * *} \\
(0.034)\end{array}$ \\
\hline Post $(t+3) \times$ Fraud Ind & $\begin{array}{l}-0.030 \\
(0.035)\end{array}$ & $\begin{array}{l}-0.154 * * * \\
(0.047)\end{array}$ & $\begin{array}{l}-0.312 * * * \\
(0.085)\end{array}$ & $\begin{array}{l}-0.065^{* *} \\
(0.031)\end{array}$ \\
\hline Post $(t+4) \times$ Fraud Ind. & $\begin{array}{l}-0.074 \\
(0.047)\end{array}$ & $\begin{array}{l}-0.107 * * \\
(0.043)\end{array}$ & $\begin{array}{l}-0.263^{* * *} \\
(0.088)\end{array}$ & $\begin{array}{l}-0.073 * * \\
(0.037)\end{array}$ \\
\hline $\operatorname{Post}(t+5) \times$ Fraud Ind & $\begin{array}{l}-0.095^{*} \\
(0.056)\end{array}$ & $\begin{array}{l}-0.138^{* * * *} \\
(0.045)\end{array}$ & $\begin{array}{l}-0.296^{* * * *} \\
(0.078)\end{array}$ & $\begin{array}{l}-0.103 * * \\
(0.044)\end{array}$ \\
\hline $\operatorname{Post}(t+6) \times$ Fraud Ind & $\begin{array}{l}-0.063 \\
(0.056)\end{array}$ & $\begin{array}{l}-0.132 * * * \\
(0.044)\end{array}$ & $\begin{array}{l}-0.183 * * \\
(0.079)\end{array}$ & $\begin{array}{l}-0.083^{*} \\
(0.045)\end{array}$ \\
\hline $\operatorname{Post}(t+7) \times$ Fraud Ind & $\begin{array}{l}-0.070 \\
(0.058)\end{array}$ & $\begin{array}{l}-0.152 * * * \\
(0.043)\end{array}$ & $\begin{array}{l}-0.269 * * * \\
(0.078)\end{array}$ & $\begin{array}{l}-0.090 * * \\
(0.044)\end{array}$ \\
\hline Post $(t+8) \times$ Fraud Ind. & $\begin{array}{l}-0.091 \\
(0.059)\end{array}$ & $\begin{array}{l}-0.185 * * * \\
(0.053)\end{array}$ & $\begin{array}{l}-0.196 * * \\
(0.078)\end{array}$ & $\begin{array}{l}-0.126^{* * * *} \\
(0.047)\end{array}$ \\
\hline Controls and main effects & $\begin{array}{c}\text { Yes } \\
\text { Year } x\end{array}$ & $\begin{array}{c}\text { Yes } \\
\text { Year } x\end{array}$ & $\begin{array}{c}\text { Yes } \\
\text { Year } x\end{array}$ & $\begin{array}{c}\text { Yes } \\
\text { Year } x\end{array}$ \\
\hline Fixed Effects & $\begin{array}{c}\text { Industry } \times \\
\text { County, } \\
\text { Worker }\end{array}$ & $\begin{array}{c}\text { Industry } \times \\
\text { County, } \\
\text { Worker }\end{array}$ & $\begin{array}{c}\text { Industry } \times \\
\text { County, } \\
\text { Worker }\end{array}$ & $\begin{array}{c}\text { Industry } \times \\
\text { County, } \\
\text { Worker }\end{array}$ \\
\hline Observations & $4,508,000$ & $4,507,000$ & 329,000 & $8,694,000$ \\
\hline R-squared & 0.654 & 0.630 & 0.736 & 0.633 \\
\hline
\end{tabular}




\section{Table 7. Employee Earnings, Movements, and Pre-Fraud Wage Levels}

This table reports estimates from OLS regression analyses estimating equation (2): estimates for wage effects at fraud firms in the by-event-time years. We divide the sample conditional on worker movements in columns (1)-(3). In column (1), we limit the sample to workers who leave the fraud or matched control firm prior to or in period Post $(t+5)$, i.e., leaves at the latest three years after the fraud concludes. In column (2), we limit the sample to workers who leave in period Fraud $_{t}$, i.e., the first year of the fraud. In column (3), we limit the sample to workers who remain with the fraud or matched control firm through at least period $\operatorname{Post}(t+5)$, i.e., stays at least three years after the fraud concludes. In columns (4) and (5), we present subsamples of employees in the top $10 \%$ and bottom $90 \%$ of the pre-fraud wage distribution, respectively. We present estimates from specifications with Year $\times$ Industry $\times$ County effects throughout. Appendix Table A defines variables. Standard errors are in parentheses and calculated with clustering by pre-fraud employer (i.e., fraud firm or matched control firm). Statistical significance at the $10 \%, 5 \%$, and $1 \%$ levels is indicated by $*, * *$, and $* * *$, respectively. Number of observations are rounded to comply with disclosure requirements of the U.S. Census Bureau.

Dependent Variable $=$ Ln(Annual Real Wages)

Pre $(t-4) \times$ Fraud Ind .

Pre(t-3) $\times$ Fraud Ind .

Pre(t-2) $\times$ Fraud Ind .

$\operatorname{Pre}(t-1) \times$ Fraud Ind .

Fraud $(t) \times$ Fraud Ind.

Fraud $(t+1) \times$ Fraud Ind

$\operatorname{Fraud}(t+2) \times$ Fraud $I n d$.

$\operatorname{Post}(t+3) \times$ Fraud Ind .

$\operatorname{Post}(t+4) \times$ Fraud Ind .

Post $(t+5) \times$ Fraud Ind .

Post $(t+6) \times$ Fraud Ind .

Post $(t+7) \times$ Fraud Ind .

Post $(t+8) \times$ Fraud Ind .

Controls and main effects

Fixed Effects
(1)

(2)

Early

Leavers

$0.006 \quad-0.019$

(0.015)

$-0.004$

(0.023)

0.019

(0.030)

0.001

(0.028)

$-0.051 * *$

(0.026)

$-0.082 * *$

(0.035)

-0.089 ***

(0.033)

$-0.057^{*}$

(0.030)

$-0.050$

(0.037)

$-0.099 * *$

(0.044)

$-0.101 * *$

(0.046)

$-0.112 * *$

(0.047)

$-0.137 * * *$

(0.050)

Yes

Year $x$

Industry $x$

County,

Worker

4,837,000

0.604

\section{(0.019)}

$-0.045^{*}$

(0.024)

$-0.002$

(0.034)

$-0.024$

(0.036)

$-0.047$

(0.043)

$-0.069$

(0.046)

$-0.096^{* *}$

(0.044)

$-0.041$

(0.036)

$-0.040$

(0.041)

$-0.066$

(0.049)

$-0.076$

(0.050)

$-0.095^{*}$

(0.054)

$-0.114 * *$

(0.054)

Yes

Year $x$

Industry $x$

County,

Worker

920,000

0.585
(3)

(4)

(5)

Bottom

\section{\begin{tabular}{l|l} 
Stayers & Top
\end{tabular}}

$10 \%$

0.007

(0.025)

$-0.007$

(0.028)

0.030

(0.037)

0.068

(0.072)

$-0.017$

(0.076)

$-0.035$

(0.060)

$-0.026$

(0.060)

$-0.040$

(0.055)

0.005

(0.059)

0.016

(0.063)

0.033

(0.052)

$-0.022$

(0.044)

$-0.036$

(0.044)

Yes

Year $x$

Industry $x$

County,

Worker

893,000

0.555
90\%

$-0.010$

(0.015)

$-0.008$

(0.022)

0.032

(0.029)

0.012

(0.033)

$-0.072 * *$

(0.031)

$-0.084 * *$

(0.037)

$-0.099 * * *$

(0.032)

$-0.081 * * *$

(0.031)

$-0.088 * *$

(0.035)

$-0.121 * * *$

(0.041)

$-0.099 * *$

(0.043)

$-0.104 * *$

(0.043)

$-0.134 * * *$

(0.046)

Yes

Year $x$

Industry $x$

County,

Worker

$8,132,000$

$8,132,000$
0.586 


\section{Table 8. Dynamics of Earnings for Newly Hired Employees at Fraud Firm}

This table reports estimates from OLS regression analyses estimating equation (2): estimates for wage effects at fraud firms in the by-event-time years. We use a separate sample of newly hired employees that first receive wages at the

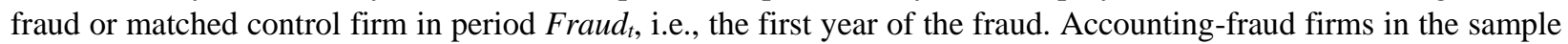
commit financial misrepresentation from 1991 to 2008 according to the AAER. Appendix Table A defines variables. Standard errors are in parentheses and calculated with clustering by fraud-period employer (i.e., fraud firm or matched control firm). Statistical significance at the $10 \%, 5 \%$, and $1 \%$ levels is indicated by *,**, and ***, respectively. Number of observations are rounded to comply with disclosure requirements of the U.S. Census Bureau.

\begin{tabular}{|c|c|c|c|}
\hline $\begin{array}{l}\text { Dependent Variable }= \\
\text { Ln(Annual Real Wages })\end{array}$ & $\begin{array}{c}\text { (1) } \\
\text { Year } \\
\text { Effects }\end{array}$ & $\begin{array}{c}(2) \\
\text { Year- Industry } \\
\text { Effects }\end{array}$ & $\begin{array}{c}(3) \\
\text { Year- Industry- } \\
\text { County } \\
\text { Effects }\end{array}$ \\
\hline Pre $(t-4) \times$ Fraud Ind. & $\begin{array}{l}-0.025 \\
(0.024)\end{array}$ & $\begin{array}{l}-0.007 \\
(0.018)\end{array}$ & $\begin{array}{l}-0.020^{*} \\
(0.011)\end{array}$ \\
\hline Pre $(t-3) \times$ Fraud Ind. & $\begin{array}{l}-0.044 \\
(0.030)\end{array}$ & $\begin{array}{l}-0.016 \\
(0.020)\end{array}$ & $\begin{array}{l}-0.022 \\
(0.015)\end{array}$ \\
\hline $\operatorname{Pre}(t-2) \times$ Fraud Ind. & $\begin{array}{l}-0.084 * * \\
(0.034)\end{array}$ & $\begin{array}{l}-0.057 * * * \\
(0.021)\end{array}$ & $\begin{array}{l}-0.041 * * \\
(0.019)\end{array}$ \\
\hline $\operatorname{Pre}(t-1) \times$ Fraud Ind. & $\begin{array}{l}-0.046 \\
(0.057)\end{array}$ & $\begin{array}{l}-0.013 \\
(0.036)\end{array}$ & $\begin{array}{l}-0.025 \\
(0.032)\end{array}$ \\
\hline Fraud $(t) \times$ Fraud Ind & $\begin{array}{l}-0.036 \\
(0.046)\end{array}$ & $\begin{array}{c}0.067 \\
(0.044)\end{array}$ & $\begin{array}{l}0.080^{*} \\
(0.041)\end{array}$ \\
\hline $\operatorname{Fraud}(t+1) \times$ Fraud $\operatorname{Ind}$. & $\begin{array}{l}-0.171 * * * \\
(0.058)\end{array}$ & $\begin{array}{l}-0.053 * \\
(0.029)\end{array}$ & $\begin{array}{l}-0.022 \\
(0.026)\end{array}$ \\
\hline Fraud $(t+2) \times$ Fraud Ind. & $\begin{array}{l}-0.178 * * * \\
(0.048)\end{array}$ & $\begin{array}{l}-0.060 * * \\
(0.024)\end{array}$ & $\begin{array}{l}-0.013 \\
(0.023)\end{array}$ \\
\hline Post $(t+3) \times$ Fraud Ind & $\begin{array}{l}-0.191 * * * \\
(0.049)\end{array}$ & $\begin{array}{l}-0.069 * * * \\
(0.024)\end{array}$ & $\begin{array}{l}-0.023 \\
(0.023)\end{array}$ \\
\hline $\operatorname{Post}(t+4) \times$ Fraud Ind. & $\begin{array}{l}-0.179 * * * \\
(0.040)\end{array}$ & $\begin{array}{l}-0.073 * * * \\
(0.026)\end{array}$ & $\begin{array}{l}-0.027 \\
(0.019)\end{array}$ \\
\hline Post $(t+5) \times$ Fraud Ind & $\begin{array}{l}-0.193 * * * \\
(0.040)\end{array}$ & $\begin{array}{l}-0.080 * * * \\
(0.023)\end{array}$ & $\begin{array}{l}-0.046 * * \\
(0.019)\end{array}$ \\
\hline $\operatorname{Post}(t+6) \times$ Fraud Ind & $\begin{array}{l}-0.188 * * * \\
(0.042)\end{array}$ & $\begin{array}{l}-0.083 * * * \\
(0.027)\end{array}$ & $\begin{array}{l}-0.037^{*} \\
(0.020)\end{array}$ \\
\hline $\operatorname{Post}(t+7) \times$ Fraud Ind & $\begin{array}{l}-0.194 * * * \\
(0.043)\end{array}$ & $\begin{array}{l}-0.100 * * * \\
(0.027)\end{array}$ & $\begin{array}{l}-0.048 * * \\
(0.021)\end{array}$ \\
\hline Post $(t+8) \times$ Fraud Ind & $\begin{array}{l}-0.192 * * * \\
(0.045)\end{array}$ & $\begin{array}{l}-0.090 * * * \\
(0.027)\end{array}$ & $\begin{array}{l}-0.049 * * \\
(0.021)\end{array}$ \\
\hline Controls and main effects & Yes & Yes & Yes \\
\hline Fixed Effects & $\begin{array}{l}\text { Year, } \\
\text { Worker }\end{array}$ & $\begin{array}{c}\text { Year } \times \\
\text { Industry, } \\
\text { Worker }\end{array}$ & $\begin{array}{c}\text { Year } \times \\
\text { Industry } \times \\
\text { County, } \\
\text { Worker }\end{array}$ \\
\hline Observations & $3,289,000$ & $3,289,000$ & $3,265,000$ \\
\hline R-squared & 0.587 & 0.619 & 0.651 \\
\hline
\end{tabular}


Figure 1: A Framework for the Impact of Fraud on Labor Markets

Feature of Accounting Fraud

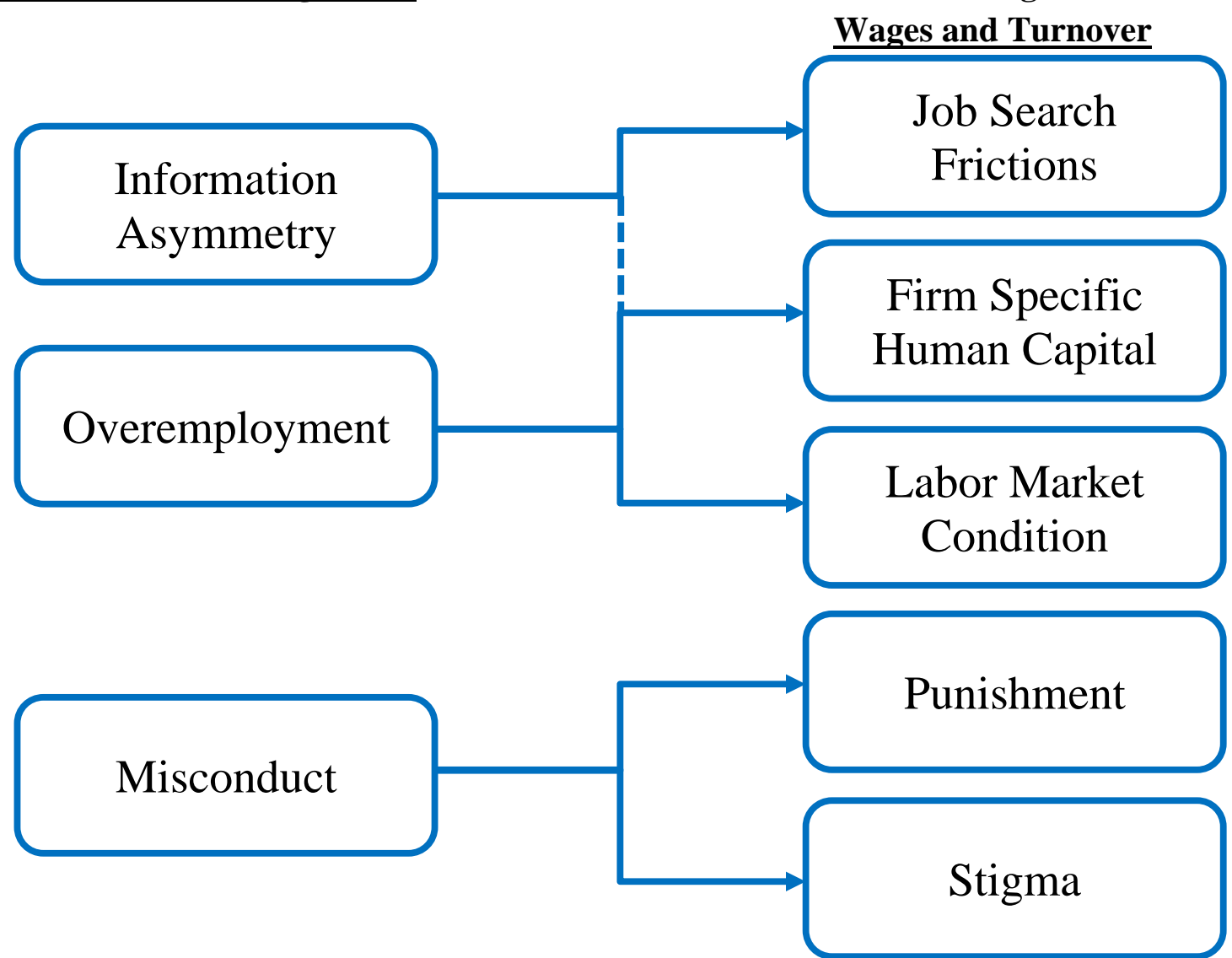

This figure depicts graphically the discussion in Section 2. We show features of accounting fraud in the leftmost set of boxes and associate these features with mechanisms that could affect labor costs (i.e., worker wages and turnover) in the rightmost set of boxes. 


\section{Figure 2: A Fraud Example, Timeline, and Employees}

Fraud Firm Timeline:

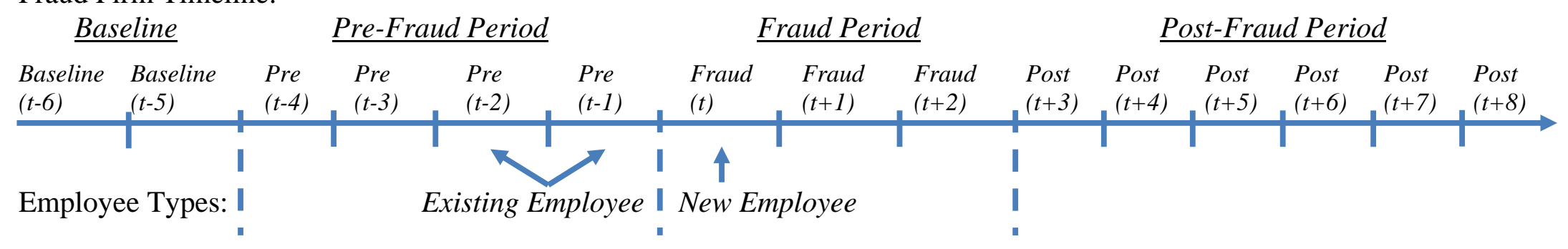

This figure is a representation of the accounting-fraud timeline. The fraud is split into three periods. The "Baseline" period is the first two years prior to the three periods of interest, Baselinet-6 and Baselinet-5. The "Pre-Fraud Period" extends for up to four years prior to the beginning of the fraud from the Accounting and Auditing Enforcement Release (AAER). We indicate these years as Pre( $t$-4), Pre $(t$ $3)$, Pre(t-2), and Pre(t-1). The "Fraud Period" extends for the length of the fraud and must result in misreporting of an annual financial statement (e.g., a single quarter of fraud that is corrected within a fiscal year would be excluded). The Fraud Period is determined by the start year and end year of financial misrepresentation from the AAER. We indicate these years as $F r a u d(t), F r a u d(t+1)$, and $F r a u d(t+2)$. For long-lasting frauds, we normalize this period to a maximum of three years by indicating additional fraud years as $F r a u d(t+2)$. The "Post-Fraud Period" extends for up to six years after the conclusions of the fraud from the AAER. We indicate these years as Post $(t+3)$, $\operatorname{Post}(t+4), \operatorname{Post}(t+5), \operatorname{Post}(t+6), \operatorname{Post}(t+7)$, and Post $(t+8)$.

We classify employees into two types. "Existing Employees" are workers at fraud (or control) firms prior to the beginning of the fraud indicated in the AAER. We require that existing employees worked for a fraud firm or a control firm for the last two years before a fraud firm engaged in accounting fraud, Pre $(t-2)$ and Pre $(t-1)$. We do not require that we are able to observe the hire date if the employee works for the firm before our sample begins. Existing employees comprise our main sample across most tables, i.e., all except Table 7. "New Employees" are workers at fraud (or control) firms hired during the Fraud Period. We require that new employees were hired in the first year of a fraud period by a fraud firm or a control firm, Fraud( $t$ ). We report results for new employees in Table 7. 


\section{Figure 3: Employment Growth Levels}

This figure shows estimates for employment growth at fraud firms in the by-event-time years. Point estimates are growth levels at fraud and matched control firms. We use LBD data.

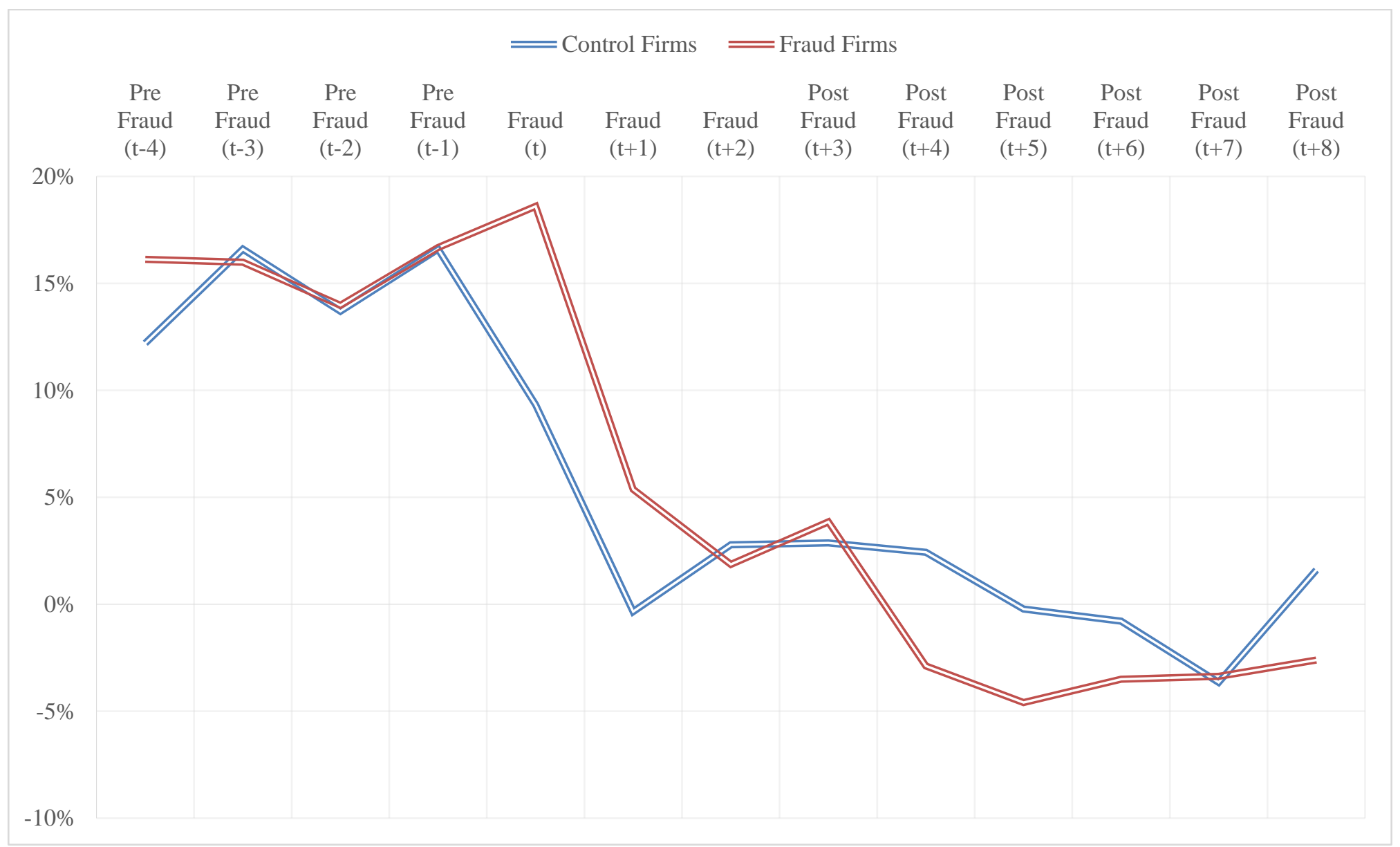




\section{Figure 4: Dynamics of Earnings for Fraud Firm Employees}

This figure shows magnitude estimates from OLS regression analyses estimating equation (2): estimates for wage effects at fraud firms in the by-event-time years. Point estimates are incremental earnings of employees at fraud firms relative to those at matched control firms. We adjust the coefficient estimates from column (3) in Table 3 to percentages. We also show 95\% confidence interval estimates as vertical bars through the point estimates; standard errors are calculated with clustering by pre-fraud employer (i.e., fraud firm or matched control firm).

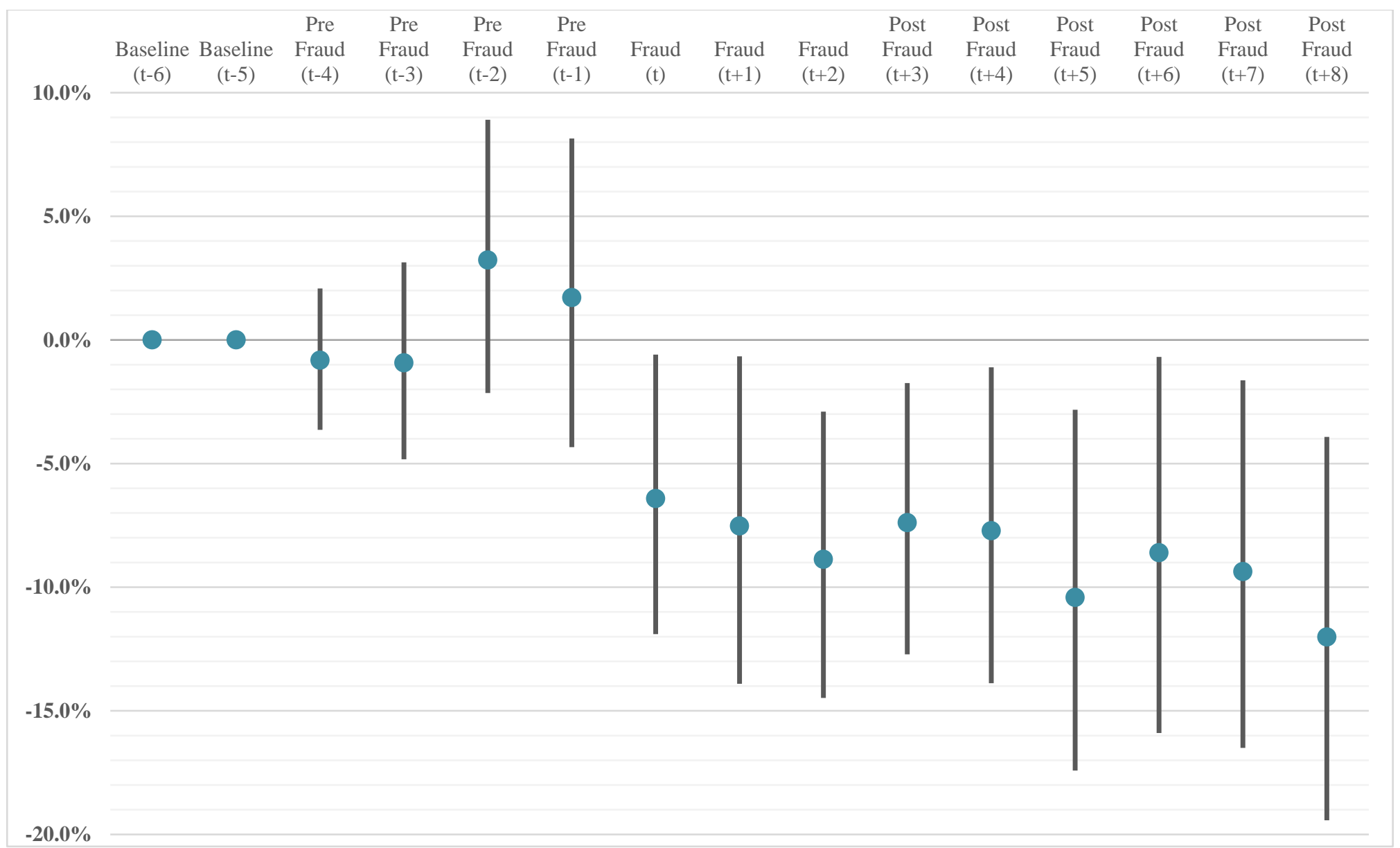




\section{Figure 5: Wage Trends for Fraud Firm Employees Conditional on Movement}

This figure shows magnitude estimates from OLS regression analyses estimating equation (2) expanded to include interactions between Fraud Ind. and indicators for fraud firm employee movements. We include indicators for Stayers, Late Leavers, and Early Leavers. We report estimates for wage effects at fraud firms in by-event-time years. Point estimates are incremental earnings of employees at fraud firms relative to those at matched control firms, pooled and not conditioned on movement.

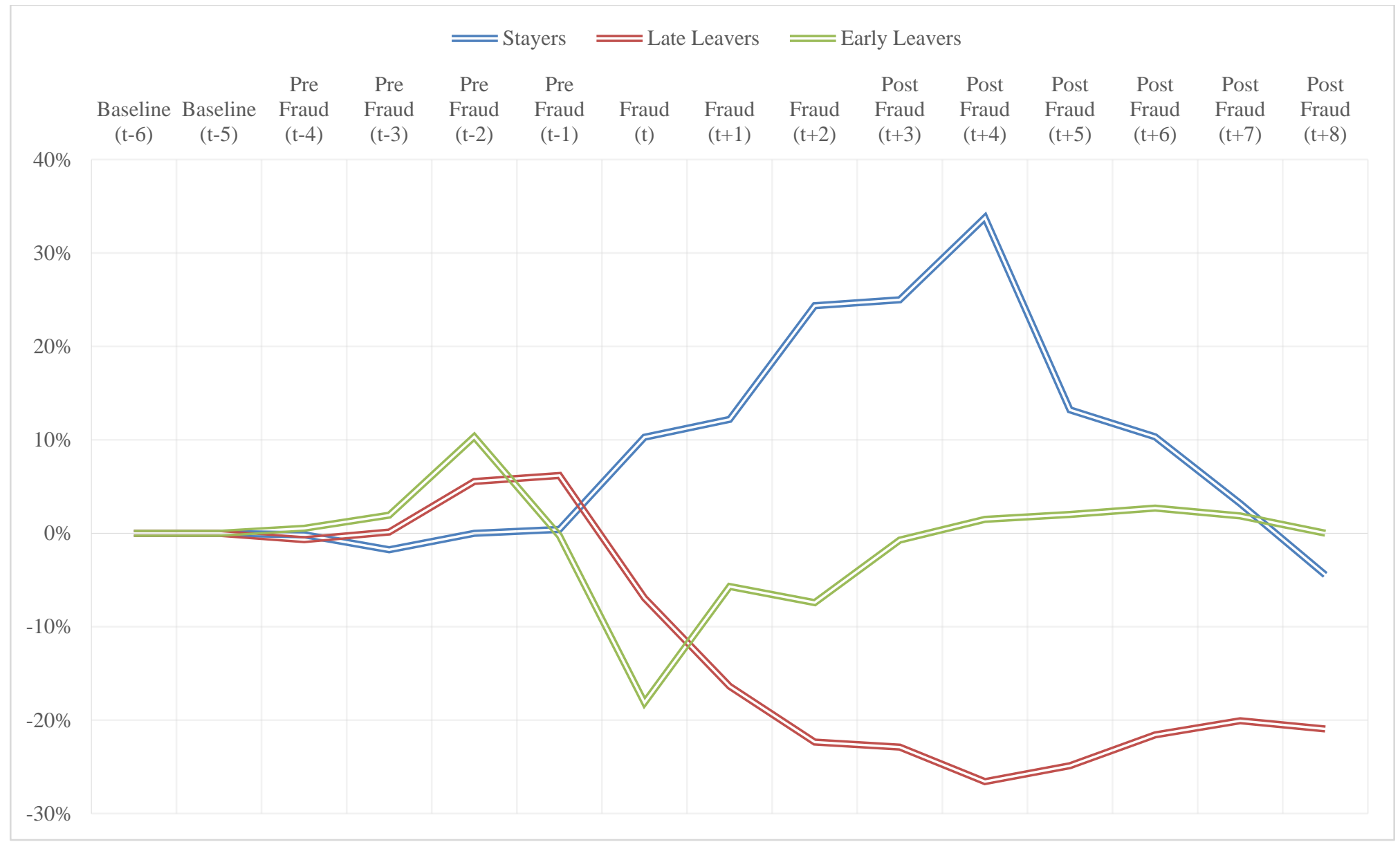




\section{Figure 6: Wage Trends across Market and Firm Heterogeneity}

This figure shows magnitude estimates from Table 6. We adjust the coefficient estimates to percentages. Wage trends are incremental for fraud firm employees relative to matched controls.

\section{Panel A: Market Heterogeneity}

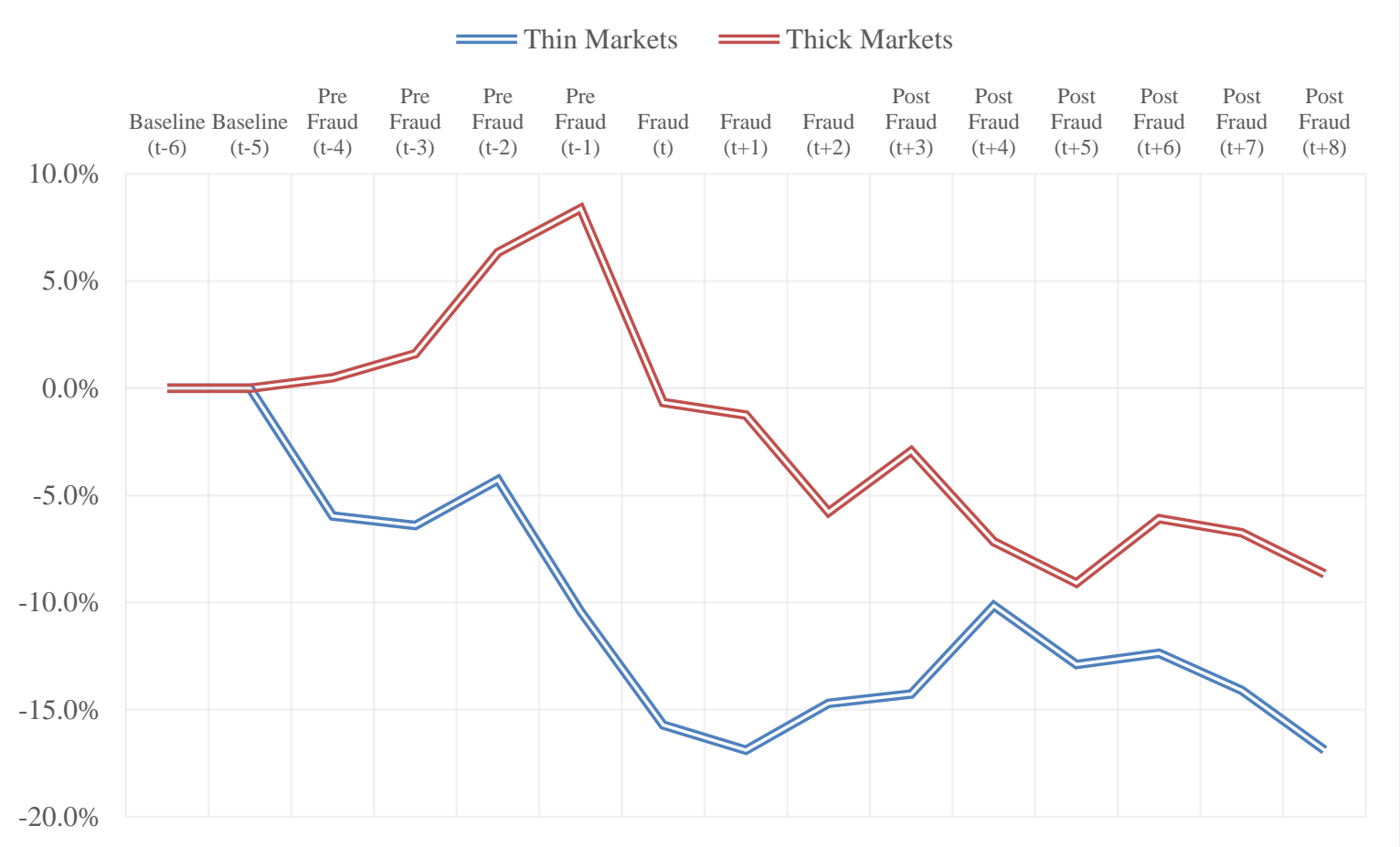

\section{Panel B: Firm Heterogeneity}

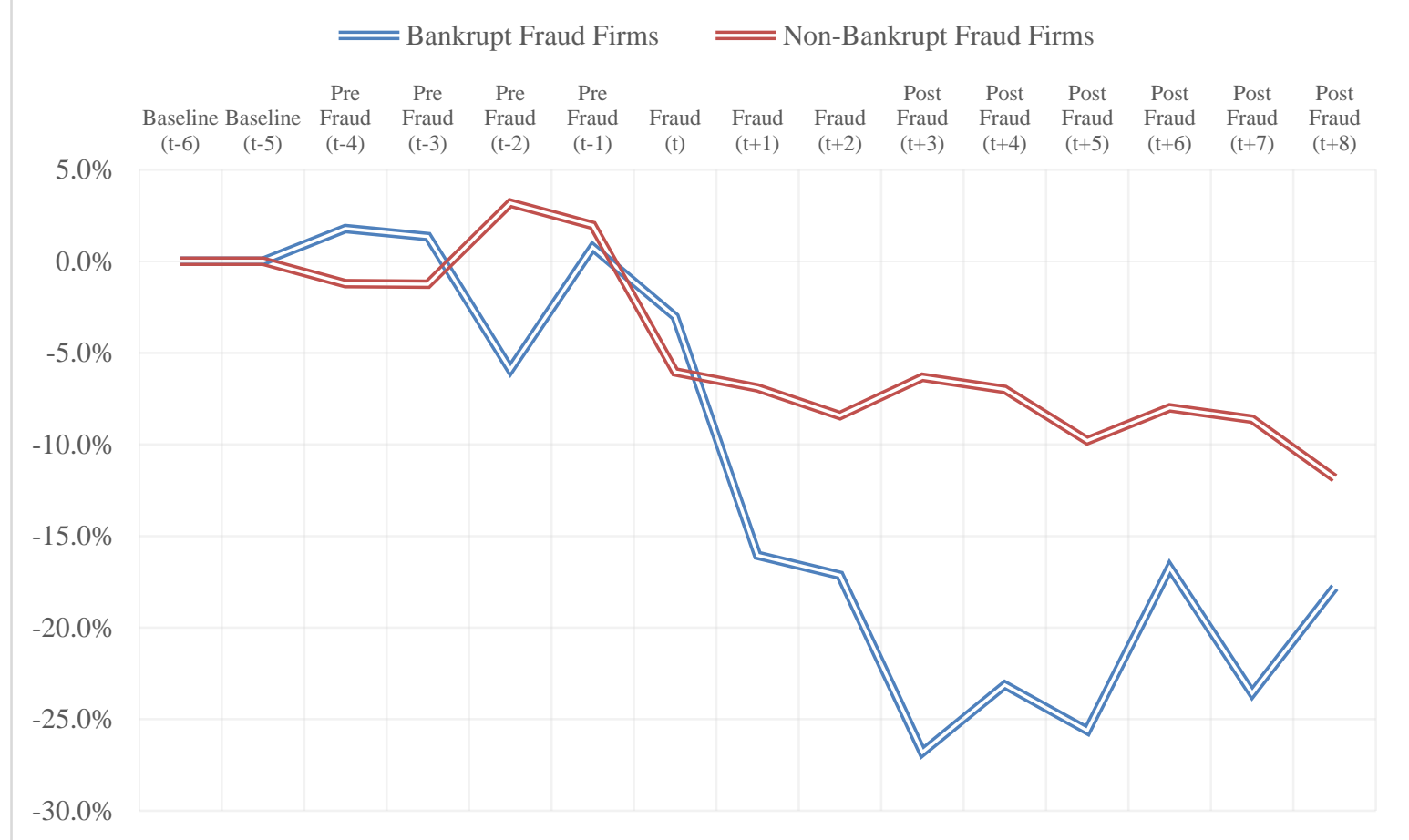




\section{Figure 7: Wage Trends across Worker Heterogeneity}

This figure shows magnitude estimates from Table 7. We adjust the coefficient estimates to percentages. Wage trends are incremental for fraud firm employees relative to matched controls.

\section{Panel A: Worker Movements}

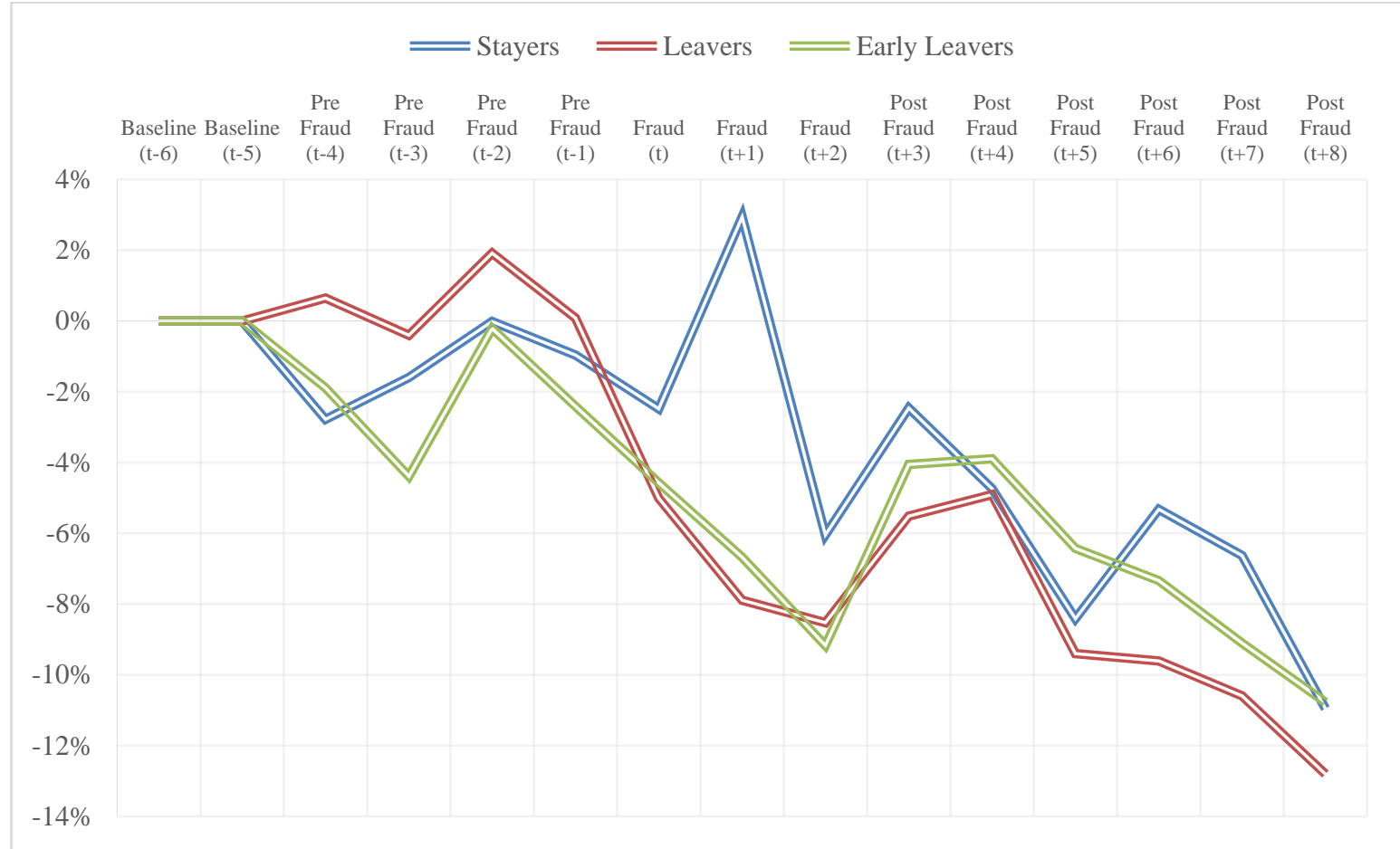

Panel B: Pre-Fraud Wage Levels

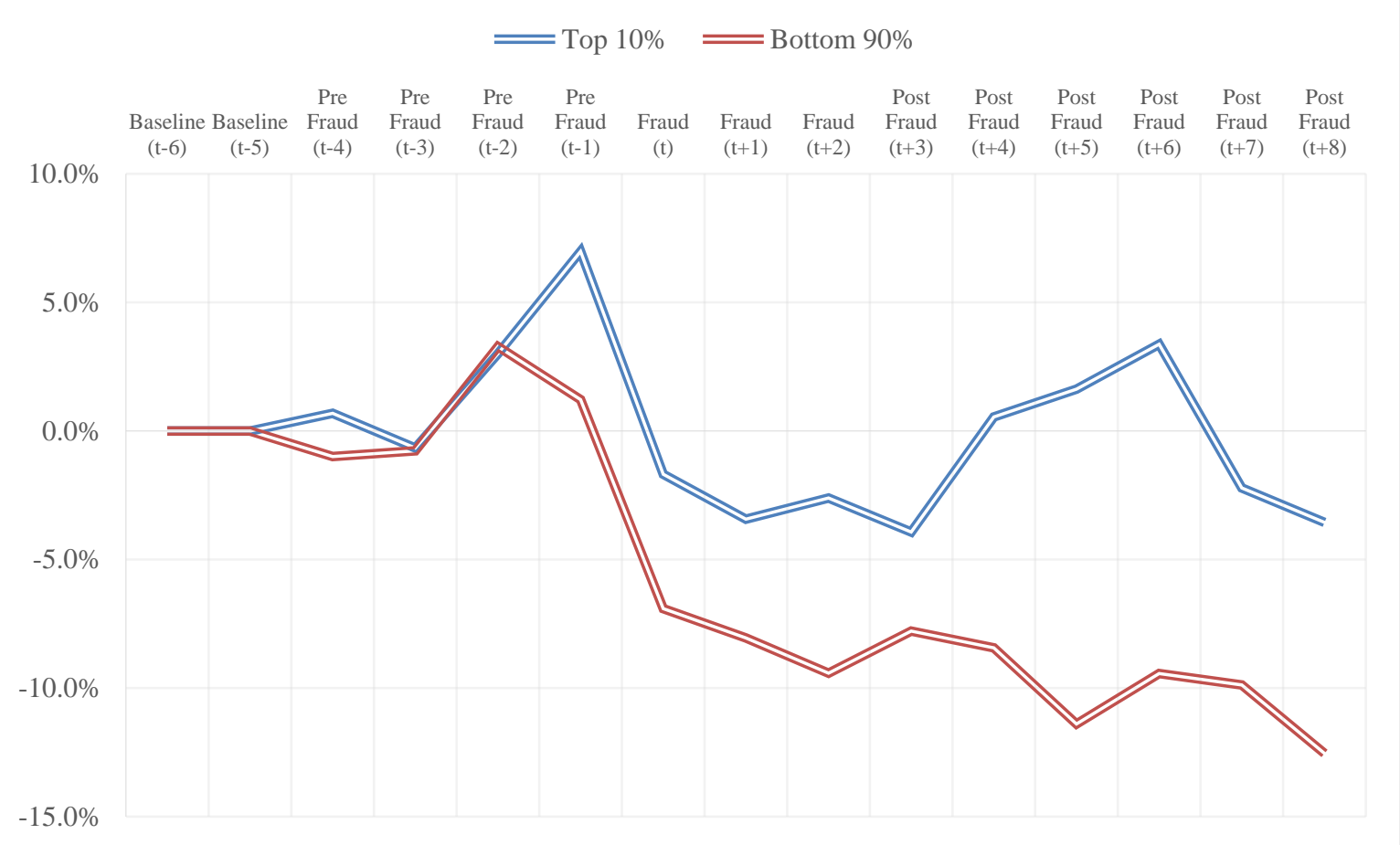




\section{Figure 8: Dynamics of Earnings for Fraud-Period-Hire Employees at Fraud Firms}

This figure shows magnitude estimates from OLS regression analyses estimating equation (2) for employees hired during the first year of the fraud, Fraud(t): estimates for wage effects at fraud firms in the by-event-time years. Point estimates are incremental earnings of employees at fraud firms relative to those at matched control firms. We adjust the coefficient estimates from column (3) in Table 8 to percentages. We also show $95 \%$ confidence interval estimates as vertical bars through the point estimates; standard errors are calculated with clustering by fraud-period employer (i.e., fraud firm or matched control firm).

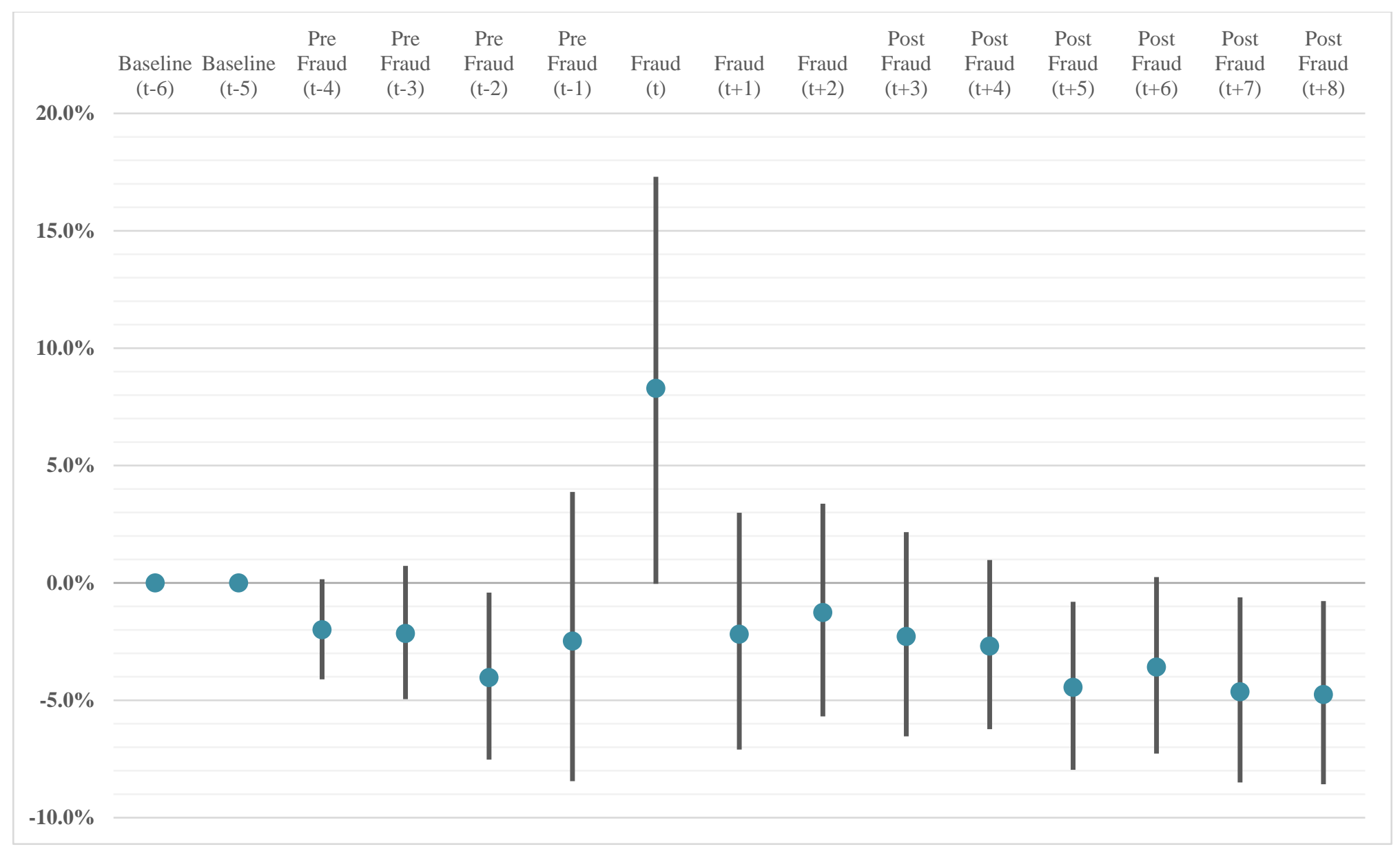

